DOE/EIA-0578(93)

Distribution Category UC-950

\title{
Energy Information Sheets
}

\author{
July 1995
}

\author{
Energy Information Administration \\ National Energy Information Center \\ U.S. Department of Energy \\ Washington, DC 20585
}

This report was prepared by the Energy Information Administration, the independent statistical agency within the Department of Energy. The information contained herein should not be construed as advocating or reflecting any policy position of the Department of Energy or any other organization.

DISTRIBUTION OF THIS DOCUMENT IS UNLIMITED 



\section{DISCLAIMER}

This report was prepared as an account of work sponsored by an agency of the United States Government. Neither the United States Government nor any agency thereof, nor any of their employees, make any warranty, express or implied, or assumes any legal liability or responsibility for the accuracy, completeness, or usefulness of any information, apparatus, product, or process disclosed, or represents that its use would not infringe privately owned rights. Reference herein to any specific commercial product, process, or service by trade name, trademark, manufacturer, or otherwise does not necessarily constitute or imply its endorsement, recommendation, or favoring by the United States Government or any agency thereof. The views and opinions of authors expressed herein do not necessarily state or reflect those of the United States Government or any agency thereof. 


\section{DISCLAIMER}

Portions of this document may be illegible in electronic image products. Images are produced from the best available original document. 


\section{Preface}

The National Energy Information Center (NEIC), as part of its mission, provides energy information and referral assistance to Federal, State, and local governments, the academic community, business and industrial organizations, and the public. The Energy Information Sheets was developed to provide general information on various aspects of fuel production, prices, consumption, and capability. Additional information on related subject matter can be found in other Energy Information Administration (EIA) publications as referenced at the end of each sheet.

Questions concerning the contents of this publication should be directed to NEIC, (202) 586-8800. Questions concerning the publication itself should be directed to Karen Vassallo at (202) 586-8315. This issue of Energy Information Sheets supersedes the previous issues. 



\section{Contents}

Page

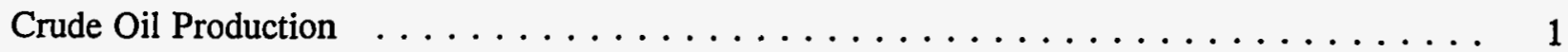

Crude Oil And Petroleum Product Prices $\ldots \ldots \ldots \ldots \ldots \ldots \ldots \ldots \ldots$

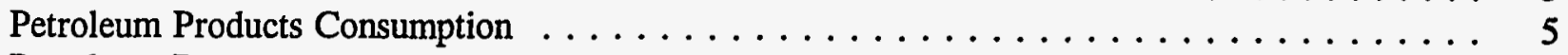

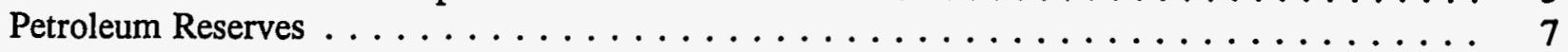

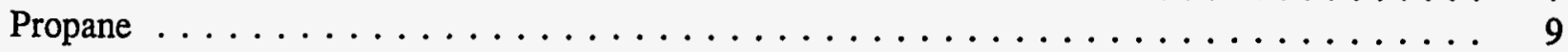

Reformulated Motor Gasoline $\ldots \ldots \ldots \ldots \ldots \ldots \ldots \ldots \ldots \ldots \ldots$

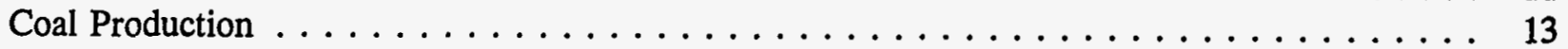

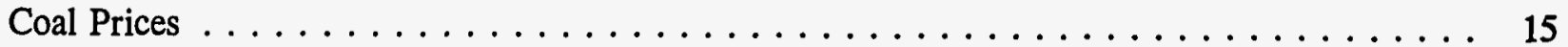

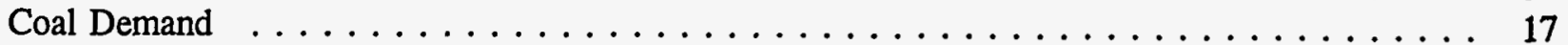

Coal Reserves ............................... 19

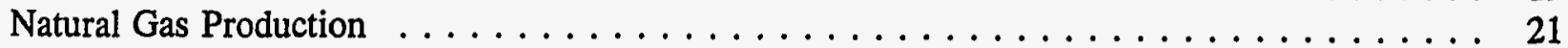

Natural Gas Prices . . . . . . . . . . . . . . . . . . . . . . 23

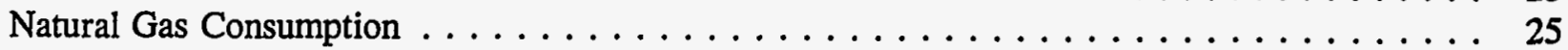

Natural Gas Reserves . . . . . . . . . . . . . . . . . . . . . . 27

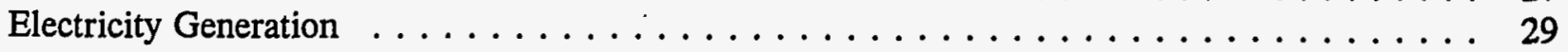

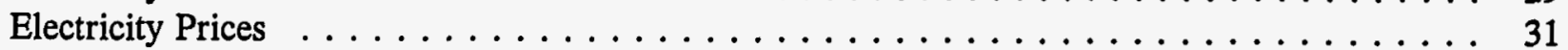

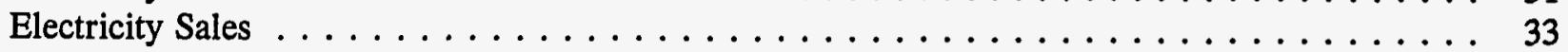

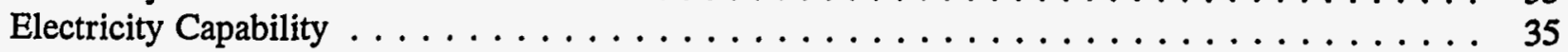

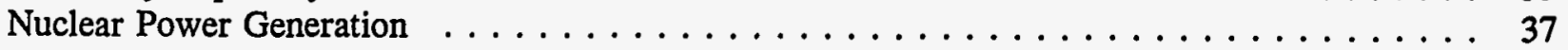

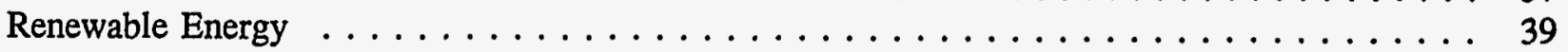

Degree-Days . . . . . . . . . . . . . . . . . . . . . . . . 41

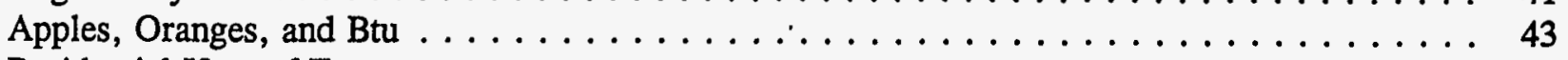

Residential Uses of Energy $\ldots \ldots \ldots \ldots \ldots \ldots \ldots \ldots \ldots \ldots \ldots \ldots \ldots$ 


\section{Crude Oil Production}

Crude oil is a product of the decayed remains of prehistoric marine animals and plants. Over centuries, organic matter and mud were subjected to extreme heat and pressures. As additional layers accumulated, the heat and pressure caused crude oil-saturated rock to form.

Crude oil is a malodorous yellow-to-black liquid usually found in underground reservoirs. Drilling a well to extract crude oil is a complicated process, but it is the only known way to confirm the existence of the oil. After initial exploration activities, site preparation begins. The type of rig system to be used, whether rotary or cable, is determined and erected. Then a derrick is constructed. A derrick is a tall structure above the hole which houses tools and pipes that go into the well. When completed, the drilled well will be turned into a production facility capable of bringing a steady flow of oil to the surface.

In 1993 , total domestic crude oil field production averaged $6,847,000$ barrels per day, a decrease of 324,000 barrels per day from the 1992 average. The top crude oil-producing States are Texas, Alaska, California, Louisiana, and Oklahoma.

Top Crude Oil-Producing States, 1993

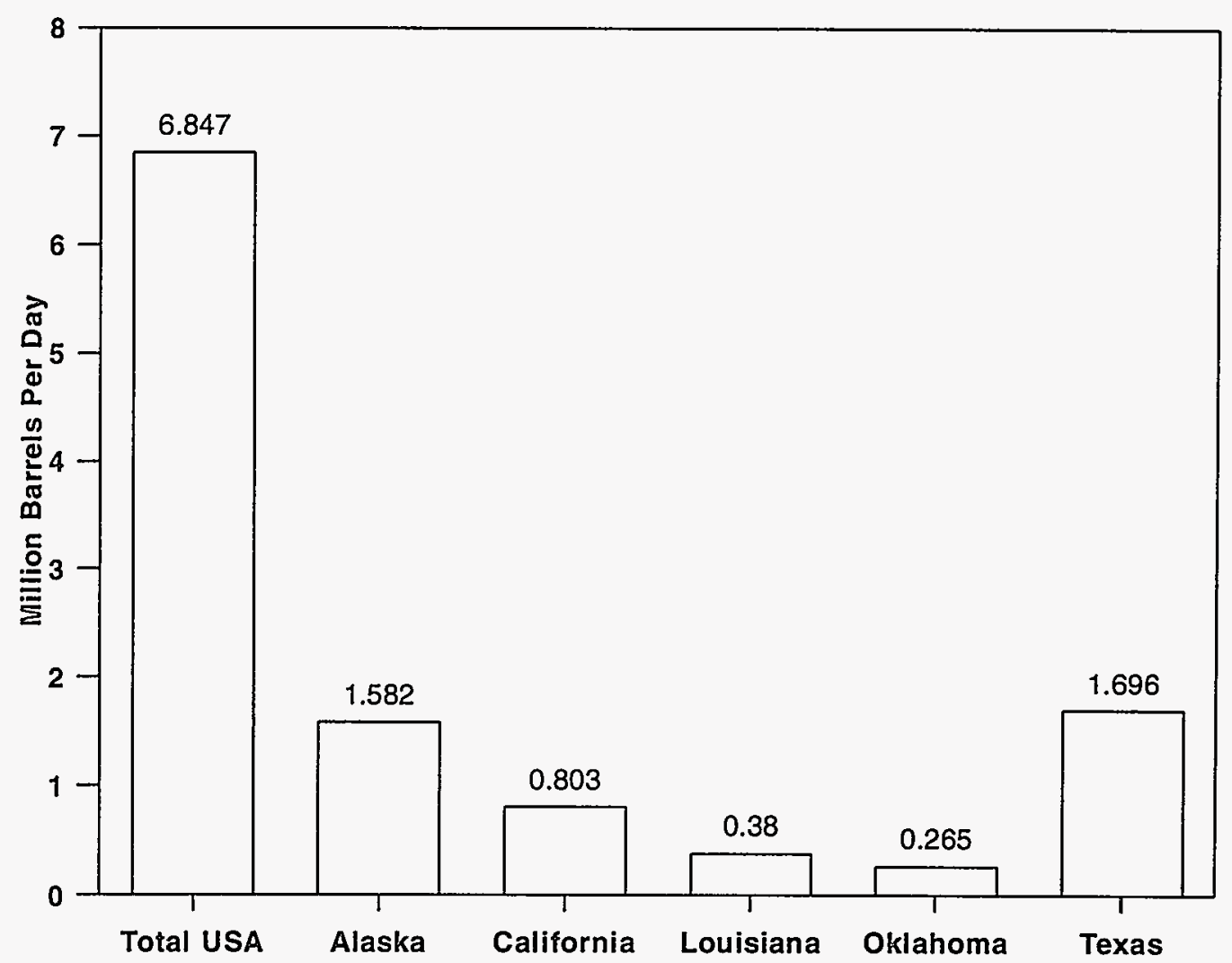

Source: Energy Information Administration, Petroleum Supply Annual 1993, DOE/ElA-0340(93)(Washington, DC, June 1994). 
Because the uses for crude oil in its natural state are limited, almost all crude is processed into finished petroleum products at a refinery. This refining process usually involves (1) distillation, or separation of the hydrocarbons that make up crude oil so that the heavier products, such as asphalt, are separated from some of the lighter products, like kerosene; (2) conversion, or cracking of the molecules to allow the refiner to squeeze a higher percentage of light products, such as gasoline, from each barrel of oil; and (3) treatment, or enhancement of the quality of the product which could entail removing sulfur from such fuels as kerosene, gasoline, and heating oils. The addition of blending components to gasolines is also a part of this process.

While getting the oil out of the ground may seem complicated, moving it from the point of production to the final consumer is just as complex. Today, there are more than 200,000 miles of pipeline in the United States.

Crude oil is measured in barrels. In 1993, one barrel of crude oil when refined typically yielded the following petroleum products in gallons:

\begin{tabular}{lr} 
Product & Gallons \\
& \\
Finished Motor Gasoline & 19.36 \\
Distillate Fuel Oil & 9.20 \\
Kero-Type Jet Fuel & 3.86 \\
Residual Fuel Oil & 2.44 \\
Still Gas & 1.93 \\
Petroleum Coke & 1.81 \\
Liquefied Refinery Gas & 1.72 \\
Asphalt and Road Oil & 1.34 \\
Petrochemical Feedstocks & 1.26 \\
Naphtha-Type Jet Fuel & 0.34 \\
Lubricants & 0.46 \\
Miscellaneous Products & 0.13 \\
Special Naphthas & 0.17 \\
Kerosene & 0.13 \\
Finished Aviation Gasoline & 0.08 \\
Waxes & 0.04 \\
\hline Total & \\
\hline
\end{tabular}

A 42-U.S. gallon barrel of crude oil yields slightly more than 44 gallons of petroleum products. This "process gain" is due to a reduction in the density of the crude oil during the refining process. The result is an increase in volume.

The United States and the former Soviet Union, along with the Organization of Petroleum Exporting Countries (OPEC), accounted for 66 percent of the total crude oil produced in the world in 1993. The United States produced 11 percent of the world's total 1993 crude oil production, and the former Soviet Union produced 12 percent.

More information on this subject can be found in the following EIA publications: Monthly Energy Review, Annual Energy Review, Petroleum Supply Monthly, and Petroleum Supply Annual. 
Crude Oil And Petroleum Product Prices

Crude oil is processed at a refinery where it is transformed into useable petroleum products. The average cost of crude oil to U.S. refineries (referred to as the "composite refiner acquisition cost") greatly affects the final cost of petroleum products. The composite refiner acquisition cost peaked in 1981 at $\$ 35.24$ per barrel. Two dramatic energy-related events of 1990 and 1991 caused a slight fluctuation in crude oil prices: the war in the Persian Gulf, which entailed the loss of Iraqi and Kuwaiti oil, and the dissolution of the former Soviet Union, the world's leading oil producer. In 1990, as a result of the Persian Gulf Crisis, the average cost rose to $\$ 22.22$ per barrel. Prices have declined steadily since then. The yearly average cost of petroleum in 1993 was $\$ 16.41$ per barrel. This was due to the relatively weak world demand for petroleum, overproduction of crude oil by the Organization of Petroleum Exporting Countries (OPEC), abundant world inventories, and continued improvements in global energy efficiencies.

Motor gasoline constitutes about half of the total volume of products produced from crude oil. Retail motor gasoline prices generally follow the same pattern as crude oil prices; however, prices fluctuate widely based on supply and demand conditions. Data from EIA indicate that taxes and factors other than the cost of crude oil account for more than half of the price paid by the consumer for a gallon of motor gasoline.

Environmental concerns have played a key role in changing the formulation of motor gasoline. The phaseout of lead in motor gasoline was brought about by a series of 1970's initiatives aimed at reducing emissions. By 1990, leaded motor gasoline represented only 5 percent of total motor gasoline sales and had been replaced almost entirely by unleaded motor gasoline. Refining processes have been changing in order to produce high octane unleaded motor gasoline, and in response to tighter restrictions on motor gasoline volatility (RVP), which became effective in 1989. Oxygenates such as methyl tertiary butyl ether (MTBE), and alcohols, such as ethanol, have become important additives for boosting the octane of motor gasoline. New specifications for oxygenated motor gasoline and reformulated motor gasoline set forth in the Clean Air Act Amendments of 1990 (CAAA) will make these additives increasingly important in the future.

The CAAA also imposed new requirements on producers, transporters, and suppliers of distillate fuel oil. Those requirements included standards for fuels designated for on-highway use of a maximum sulfur content of 0.05 percent by weight and a minimum cetane level of 40 . Further, these fuels must also be colorless to clearly designate them for use on-highway. Other diesel or distillate fuel will be dyed blue. The restrictions were designed to combat emissions of sulfur oxides, and to assure the ignition performance of the diesel fuel meets the American Society for Testing and Materials standards for combustion. The CAAA standard took effect October 1, 1993, and affects about 46 percent of the total domestic demand for distillate fuel, or about 9 percent of total U.S. petroleum demand.

No. 2 distillate includes No. 2 fuel oil and No. 2 diesel fuel. Currently these products are physically similar; however, No. 2 diesel fuel that is intended for use in passenger cars is blended with kerosene to increase its liquidity during cold weather. The cost of this process, in addition to Federal, State, and local motor fuel taxes, partially explains why No. 2 diesel fuel prices are higher than those for No. 2 fuel oil. 
The price data available for No. 2 diesel fuel are for sales through company-operated retail outlets and do not include taxes. The average U.S. sales price of No. 2 fuel oil sold to residential consumers for heating was 119.4 cents per gallon in 1981, then declined to 80.3 cents per gallon in 1987, and rebounded to 106.3 cents per gallon in 1990 , then declined to 91.1 cents per gallon in 1993. In 1983, the price of No. 2 diesel fuel averaged 94.3 cents per gallon, dropping to 88.6 cents per gallon in 1985 and to 59.8 cents per gallon in 1986. In 1990, the price had risen to 85.2 cents per gallon, dropping to 72.1 cents per gallon in 1992 and to 71.1 cents per gallon in 1993 . The sales price of No. 2 diesel through company-operated outlets has been consistently lower than No. 2 fuel oil prices but, when taxes are added, diesel is more expensive to the consumer.

Motor Gasoline Prices at the Pump, 1983-1993

(All Types)

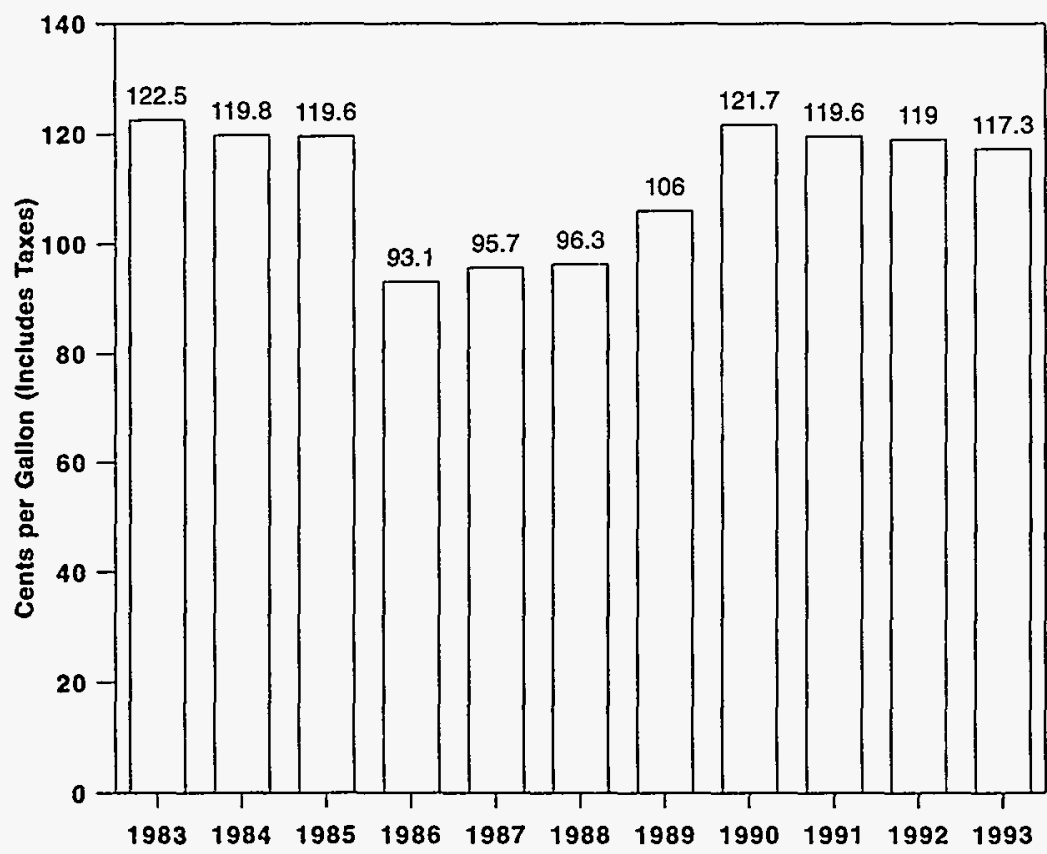

Source: Energy Information Administration, Annual Energy Review 1993, DOE/EIA-0384(93)(Washington, DC, July 1994).

Residual fuel oil is the heavy, viscous oil that remains after the other fractions have been distilled off in the refining process. It is used for generating electricity, for space heating, for industrial purposes and as fuel for ships. The average refiner's price of residual fuel oil to end users peaked at 75.6 cents per gallon in 1981. The average price was 33.7 cents per gallon in 1993.

In the late 1970's, prices of most petroleum products were subjected to Federal Government price control regulations. On January 28, 1981, all remaining product and crude oil prices were decontrolled, establishing a free market for petroleum pricing. Refiner, distributor, and retailer pricing decisions for petroleum products are now based on the operation of a free market economy and may, therefore, differ not only from region to region, but from State to State, and even from one area to another in the same State.

More information on this subject can be found in the following EIA publications: Monthly Energy Review, Annual Energy Review, Petroleum Marketing Monthly, Petroleum Marketing Annual, and Weekly Petroleum Status Report. 


\section{Petroleum Products Consumption}

Did you know that approximately 3,000 products are made from an oily substance known as petroleum? Ink, crayons, bubble gum, dishwashing liquids, deodorant, eyeglasses, records, tires, ammonia, and heart valves are just a few examples.

When crude oil was first discovered in the United States, it was taken from natural pools on the earth's surface and was used mainly for medicinal purposes. These natural pools supplied about 3 gallons of oil a day (per pool). As the population expanded and the need for the oil grew, and as whale oil, an alternative to crude oil, became scarce as a source for lighting, the need to produce more crude oil was addressed.

In Titusville, Pennsylvania, using the same technology as they used to drill for water, producers excavated the first successful oil well in 1859. As crude oil became ample, refineries sprang up to process it into useable petroleum products. The main product was kerosene, which began replacing whale oil as the prime source of illumination. Other main petroleum products refined out of a typical 42-gallon barrel (industry standard) were greases and lubricants. Today, there are many refined products, the major ones being motor gasoline, distillate fuel oil, and kerosene jet fuel. These major petroleum products heat homes and businesses and supply power to automobiles, transportation systems, and other industries.

In 1993, total U.S. demand for petroleum was 17.2 million barrels per day, of which 7.6 million barrels per day, or 44.2 percent, was from net imports (imports minus exports). Falling crude oil prices, high refinery runs and declining domestic crude oil production resulted in this highest import dependency level since 1977. Imports nearly doubled between 1970 and 1973, the year of the Arab oil embargo, rising to nearly 6.3 million barrels per day, with crude oil accounting for more than half. Net imports averaged more than 6 million barrels per day. The Organization of Petroleum Exporting Countries (OPEC) sources supplied almost 3 million barrels per day (net) of crude oil and products in 1973, or approximately 17 percent of total U.S. demand. The growth in imports was due largely to economic growth, rising personal income, and greater numbers of automobiles which stimulated demand for oil, just as domestic crude oil production, which had peaked at 9.6 million barrels per day in 1970, began to decline. In 1978, the year of peak demand, the average demand was 18.8 million barrels per day, of which 42.5 percent, or 8 million barrels per day, was from net imports.

Motor gasoline is the petroleum industry's principal refined product. A record 7.5 million barrels per day was consumed in 1993.

Distillate fuel oil consists of diesel fuels and fuel oils. Diesel fuels furnish power to diesel engines, such as those used in heavy construction equipment, trucks, buses, tractors, trains, and some automobiles. No. 2 fuel oil is utilized in the central heating of homes and small buildings. Distillate fuel oil consumption for 1993 was 3 million barrels per day, an 11-percent decrease from the 1978 high of 3.4 million barrels per day.

Residual fuel oil is heavier than distillate fuel oil; i.e., it has a higher density, viscosity, and boiling point. It is used mainly by electric utilities, large apartment and commercial buildings, and industries that 
Petroleum Products Consumption in the United States, 1973-1993

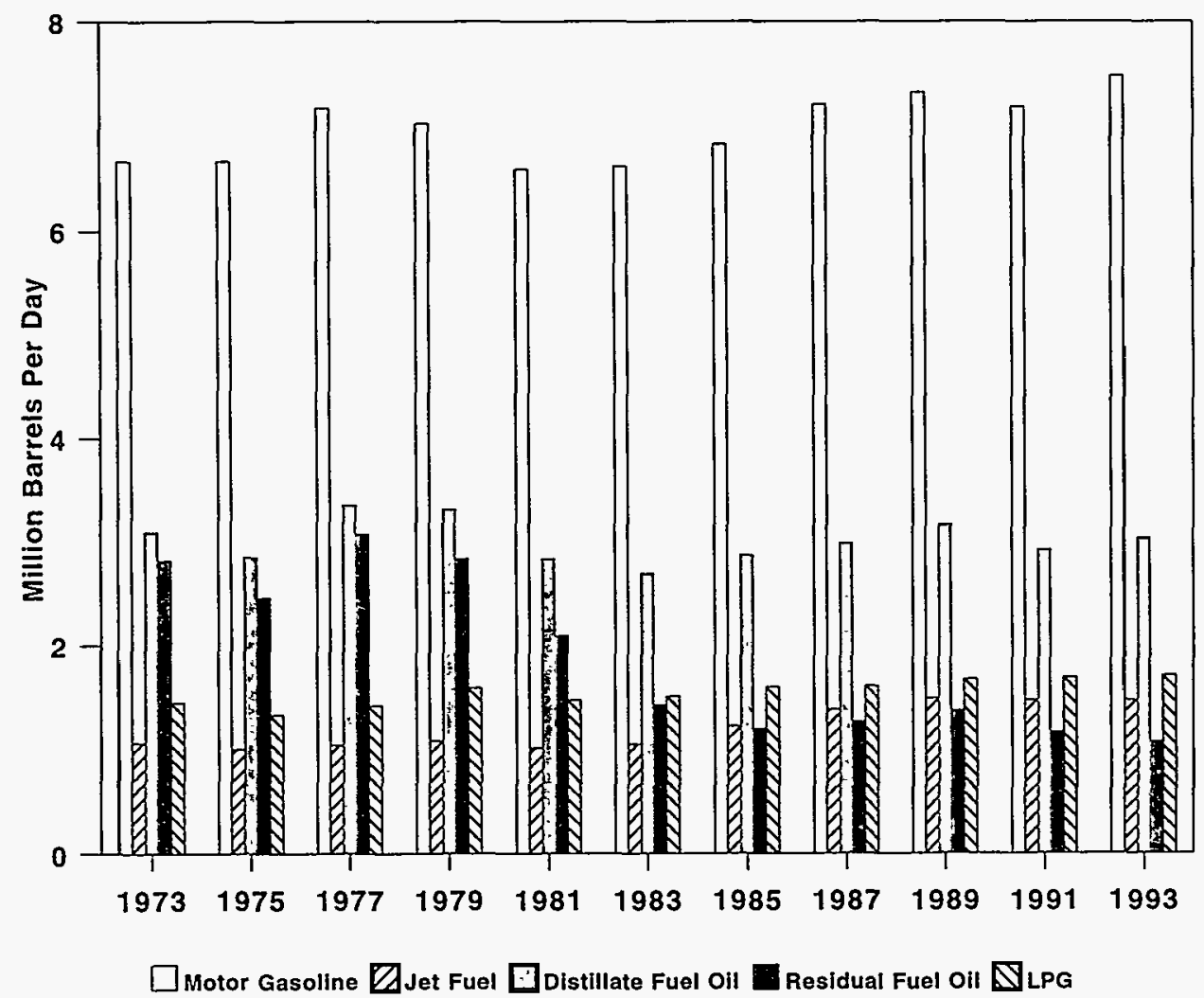

Source: Energy Information Administration, Monthly Energy Review, DOE/EIA-0035(94/04)(Washington, DC, April 1994).

maintain kilns, open-hearth furnaces, and steam boilers. Residual fuel use has declined since 1977, reaching a consumption level in 1993 of 1.1 million barrels per day, a 66-percent decrease from the 1977 high of 3.1 million barrels per day. Conservation efforts and fuel-switching are the two main reasons cited for the drop in consumption. In 1992, the three countries that consumed the most petroleum products were the United States (17 million barrels per day), Japan (5.4 million barrels per day), and Russia (4.3 million barrels per day).

More information on this subject can be found in the following EIA publications: Monthly Energy Review, Annual Energy Review, Petroleum Marketing Monthly, and International Energy Annual. 


\section{Petroleum Reserves}

Proved reserves of crude oil are the estimated quantities that geological and engineering data demonstrate, with responsible certainty, can be recovered in future years from known reservoirs, assuming existing economic and operating conditions. Proved reserves make up the domestic production base and are the primary source of oil and gas used in the United States. Total proved reserves of crude oil in the United States, as of year-end 1993, are 22.9 billion barrels, a 3-percent decrease from that of 1992 . Thirty-one States have crude oil reserves. The top five are Texas, with 6.2 billion barrels; Alaska, with 5.8 billion barrels; California, with 3.8 billion barrels; New Mexico, with 707 million barrels; and Oklahoma, with 680 million barrels. In addition, there are substantial crude oil reserves in the Federal Offshore fields: 2.1 billion barrels in the Gulf of Mexico and 673 million barrels in the Pacific.

\section{U.S. Crude Oil Proved Reserves, 1977-1993}

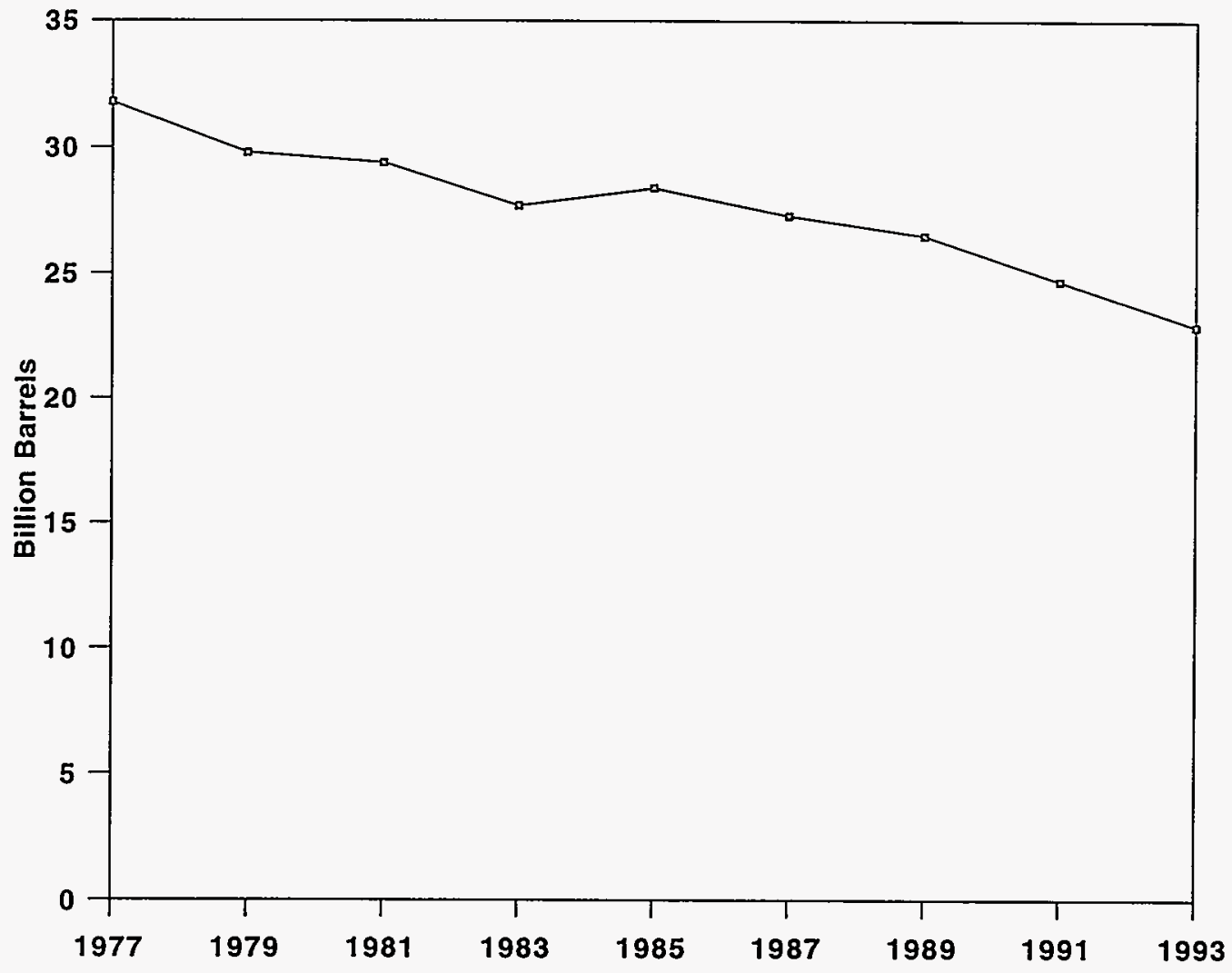

Source: Energy Information Administration, U.S. Crude Oil, Natural Gas and Natural Gas Liquids Reserves 1993, DOE/EIA$0216(93)$ (Washington, DC, October 1994).

Estimates of proved crude oil reserves do not include the following: (1) "indicated additional reserves," a category of oil that is reported separately and may become available from known reservoirs through the application of improved recovery techniques using current technology; (2) natural gas liquids (including lease condensate); (3) oil of doubtful recovery because of uncertainty as to geology, reservoir 
characteristics, or economic factors; (4) oil that may occur in undrilled prospects; and (5) oil that may be recovered from oil shales, coal, gilsonite (asphalt), and other such sources.

Volumes of crude oil placed in underground storage, such as those in the Strategic Petroleum Reserve, are not considered proved reserves. The Strategic Petroleum Reserve was created to diminish the impact of disruptions in petroleum supplies and to carry out obligations of the United States under the International Energy Program. In 1975, Public Law 94-163 (the Energy Policy and Conservation Act) established the Strategic Petroleum Reserve of up to 1 billion barrels of petroleum supplies. These petroleum stocks are to be maintained by the Federal Government for use during periods of major supply interruptions. At the end of December 1993, there were 587 million barrels of crude oil in the Reserve.

More information on this subject can be found in the following EIA publications: U.S. Crude Oil, Natural Gas, and Natural Gas Liquids Reserves Annual Report and Annual Energy Review. 


\section{Propane}

Propane, also known as "bottled gas," is a colorless paraffinic hydrocarbon. As a liquefied petroleum gas (LPG), it is classified along with ethane, butane, ethylene, butylene and propylene.

With a chemical formula of $\mathrm{C}_{3} \mathrm{H}_{8}$ and a molecular weight of 44.094 , propane occurs in both liquid and gaseous forms. At normal temperature and atmospheric pressure, it is a gas, while slight changes in pressure or temperature cause it to become a liquid. Although it is actually nontoxic and odorless, a foul-smelling sulfur-containing compound known as ethyl mercaptan is added to propane so that leaks can be easily detected.

Propane along with other LPG's can be produced at either petroleum refineries or at natural gas processing plants. After production, propane is then shipped from the refineries and processing plants to distribution terminals and underground storage facilities by pipeline and from there can be carried by truck, rail, barge or tanker.

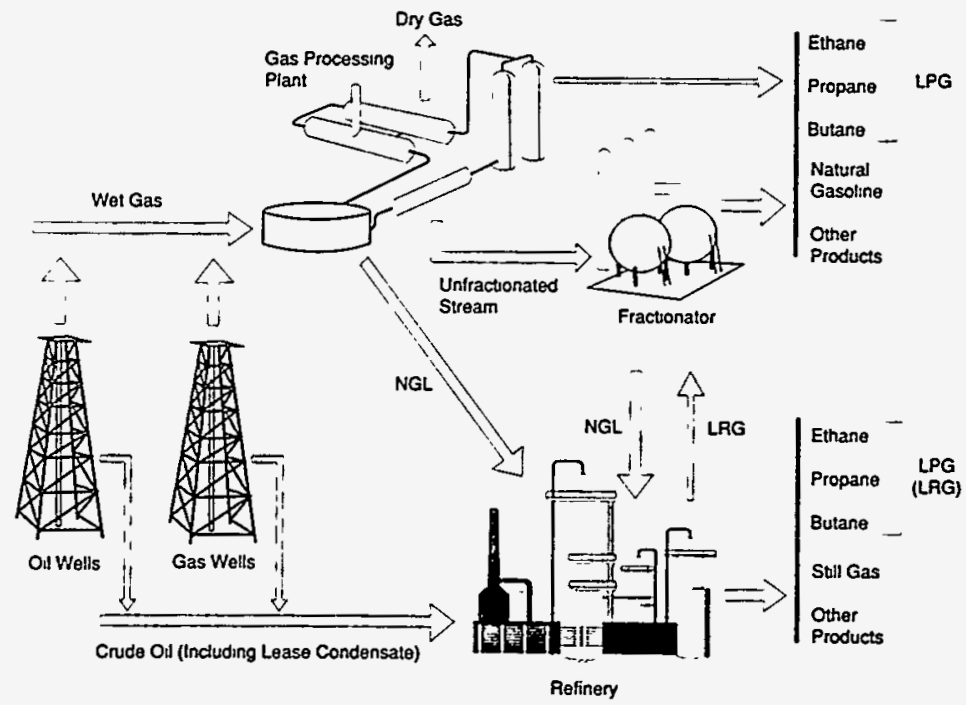

Source: Energy Information Administration, Office of Oil and Gas.

Propane is normally stored and transported in its compressed liquid form, and is often supplied in portable steel cylinders or tanks. By opening a valve to reduce pressure in the storage container, the liquid is vaporized into a gas for use. 
Of 94 million households in the United States, 8.2 million depend on propane for one use or another. The following is an outline of propane use in the major sectors of the United States:

RESIDENTIAL: Propane use by homeowners has mainly been for space heating, clothes drying and recreational outdoor cooking. Additionally, it is the principal heating fuel for mobile homes, as well as in rural areas of the United States where natural gas service is not available.

COMMERCIAL: Restaurants and caterers use propane for cooking and warming food, while warehouse owners have long chosen it to fuel forklifts.

AGRICULTURAL: Farmers have found propane useful to dry crops, warm greenhouses and chicken coops, burn weeds, and sterilize milking equipment.

TRANSPORTATION: Owners of fleets of vehicles have found clean burning propane to be an alternative fuel for use in internal combustion engines. Propane is high in octane and releases negligible amounts of emissions. When burned, propane leaves no ash and produces practically no sulfur oxides since its combustion products (carbon dioxide and water vapor) are easily absorbed into the atmosphere. For this reason, it is often used in vehicles which are run indoors or in mines.

INDUSTRIAL: Vulcanizing of rubber and metal cutting are some of the industrial uses.

UTILITIES: Propane is frequently used as a back-up fuel during peak generating periods or peak shaving periods by electric utilities. Natural gas utilities use a propane-air mixture as a supplemental fuel during periods of peak demand.

CHEMICAL: Propane has a significant part in the manufacture of petrochemical feedstock, aerosol propellants, solvents, and synthetic rubber.

Almost 90 percent of the U.S. supply of propane is derived from domestic production. Of the total, nearly half is produced at natural gas processing plants, and about 41 percent is produced at petroleum refineries. The remaining 10 percent comes from foreign sources. Import levels for 1993 totaled 37.7 million barrels while U.S. exports of propane were 9.6 million barrels. (A barrel contains 42 gallons.)

By December 1993, nationwide primary stocks--stocks held at refineries, bulk terminals, gas processing plants, and pipelines--were at 51 million barrels, a level that was slightly above the average adequate supply range for that time of year. During the warmer months, however, inventories can be as high as 61 million barrels--as seen in September 1993--while the demands of the winter heating season bring a drawdown of propane stocks.

When propane stocks are low, propane prices tend to rise. Such a typical supply/demand relationship was evidenced by 1993's refiner propane prices to end users which, excluding taxes, began the year at almost 75 cents per gallon, hovered in the low 60's in the summer, and then rose to about 64 cents a gallon by December.

More information on this subject can be found in the following EIA publications: Winter Fuels Report, Petroleum Supply Monthly, Petroleum Supply Annual, Petroleum Marketing Monthly, Petroleum Marketing Annual, and U.S. Petroleum Industry, Past as Prologue: 1970-1992. 


\section{Reformulated Motor Gasoline}

On January 1, 1995, motorists in designated areas throughout the United States began using a new cleaner motor gasoline designed to significantly reduce the pollutants emitted by motor vehicles. This gasoline, produced through an improved refining and blending formula, is known as reformulated gasoline or RFG. The sale of RFG is mandated by the Clean Air Act Amendments of 1990 (CAAA) and will be implemented through regulations promulgated by the Environmental Protection Agency (EPA).

RFG contains certain oxygen additives called oxygenates. Frequently used oxygenates include Methyl tertiary butyl ether (MTBE) and ethanol. While oxygenates have been used in some fuels as octane enhancers since the 1970's, a widespread oxygenated fuel program began in 1992 in 39 urban areas. This program was also required by the CAAA in cities with high carbon monoxide pollution. Oxygenates increase the combustion efficiency of gasoline thereby reducing vehicle emissions of carbon monoxide.

The use of RFG is required in several severe ozone "nonattainment areas." Additionally, 85 less severe ozone nonattainment areas in the United States (excluding California) are eligible to opt into the RFG program. As of December 1994, 39 Northeast localities that previously voluntarily joined the RFG program petitioned the EPA to opt-out of that commitment. After reviewing each request, the EPA granted a temporary stay of the RFG requirements in the following areas that are currently designated as ozone nonattainment areas: Maine--Counties of Hancock and Waldo; New York--Counties of Albany, Erie, Greene, Jefferson, Montgomery, Niagara, Rensselaer, Saratoga, and Schenectady; and Pennsylvania--Counties of Adams, Allegheny, Armstrong, Beaver, Berks, Blair, Butler, Cambria, Carbon, Columbia, Cumberland, Dauphin, Erie, Fayette, Lackawanna, Lancaster, Lebanon, Lehigh, Luzerne, Mercer, Monroe, Northhampton, Somerset, Perry, Washington, Westmoreland, Wyoming, and York.

These areas reported acceptable ozone levels for the last 3 years of measurement, and the EPA was in the process of redesignating them as attainment areas. The stay will be in effect through July 1, 1995, providing the EPA adequate review time before taking final action on these opt-out requests.

The regulations implementing the RFG program were issued as part of a two-phase program. Phase I will be implemented in two stages using the Simple Model and the Complex Model. The Simple Model of Phase I may be used from January 1, 1995, through December 31, 1997, and requires that gasoline meets the certain fuel content specifications and/or performance standards as set forth by the EPA. The Complex Model of Phase I may be used as early as the beginning of 1995, but becomes mandatory January 1, 1998. The Complex Model expands the performance standards that a refiner must meet in order to certify its fuel as RFG based on oxygenate type, sulfur content, olefin content and fuel distillation. Though refiners are allowed to choose either the Simple or the Complex Model for the 19951997 period, they must remain consistent with the model they choose. Switching back and forth between models will not be permitted.

The introduction of RFG as a new product represents challenges to refiners in the form of additional processing steps plus blending components, and to distributors in the form of increased product segregation. It is believed that the production of RFG will require significant changes to be made to present refinery operations. Industry estimates for these capital investments have run as high as $\$ 4$ billion.

Energy Information Administration

Energy Information Sheets 
The most visible impact on consumers in the affected areas will be a modest increase in the per gallon price of reformulated gasoline over conventional grades. There will be no discernable difference in engine performance. RFG will have no adverse effect on car performance or engine durability. Any effect on gas mileage will be modest. Studies by the EPA have shown that the vapors given off by cleaner gasoline at the pump are no more noxious than the previous gasoline formula. Motorists travelling outside of a geographic area using RFG may fill their tanks up with the older gasoline with no effect on engine or driving. Since the new RFG has a higher oxygen level than conventional gasoline, RFG will burn with less evaporation. It will reduce ozone (smog)-forming compounds and toxic chemicals such as benzene in fuel by 15 percent to 17 percent. In fact, in the first year, the new cleaner fuel will reduce smog producing emissions by 305,000 tons, which is the equivalent of removing 8.1 million cars from U.S. roads. Nearly 1.3 million tons of smog producing emissions will be removed from the air in the first 5 years. By the year 2000, RFG will reduce toxic emissions by 20 percent to 22 percent and nitrogen oxides by 5 percent to 7 percent.

Areas Affected by the Pleformulated and Oxygenated Gasoline Programs in 1995

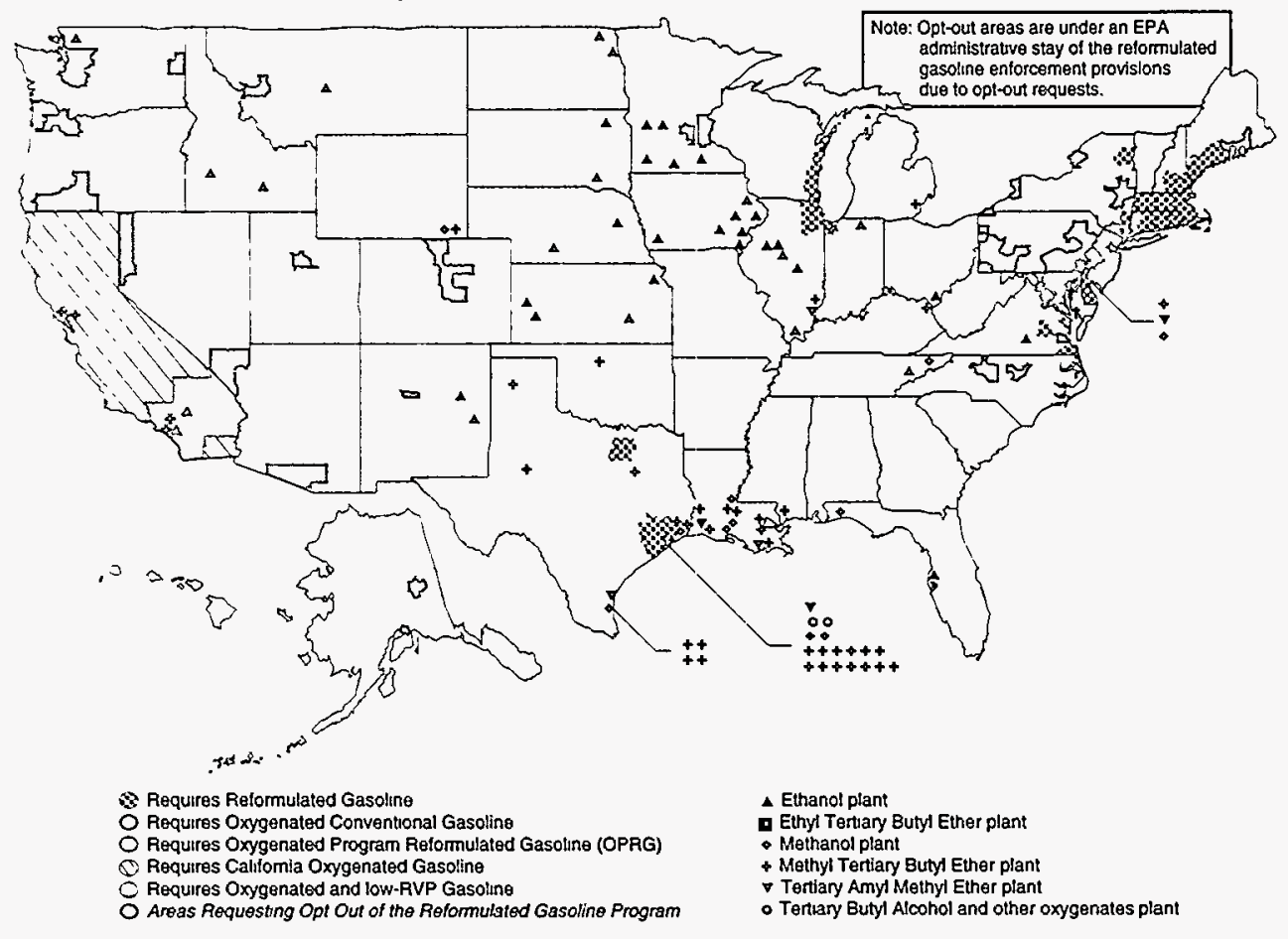

Source: Energy Information Administration, Office of Oil and Gas.

In January 1995, production of RFG averaged about 1.7 million barrels per day. Stocks at the end of January were 39.5 million barrels while imports averaged 90 thousand barrels per day. Because of the recent opt-outs of counties in Maine, New York, and Pennsylvania, EIA estimates an approximate 200 thousand-barrel-per-day reduction resulting in an anticipated January 1995 RFG demand of 1.9 million barrels per day.

More information on this subject can be found in the following EIA publications: The Energy Information Administration's Assessment of Reformulated Gasoline, Short-Term Energy Outlook, Petroleum Marketing Monthly, and Weekly Petroleum Status Report. 


\section{Coal Production}

Coal, a fossil fuel like petroleum and natural gas, is a sedimentary organic rock that contains more than 50 percent carbonaceous material by weight. It is composed largely of carbon, hydrogen, oxygen, nitrogen, and sulfur, with smaller amounts of other materials ranging from aluminum to zirconium.

Coal had its beginning as plants that grew in swamps millions of years ago. Geological processes working over vast spans of time compressed and altered the plant remains, increasing the percentage of carbon present, thereby producing the different ranks of coal: lignite, subbituminous, bituminous, and anthracite.

In the United States, lignite is mined chiefly in Texas, North Dakota, and Louisiana; and subbituminous coal is mined principally in Wyoming. Bituminous coal is mined mostly in the Appalachian and Interior Regions, while anthracite, the highest ranking coal, is mined only in northeastern Pennsylvania. About 61 percent of the coal produced in the Nation is bituminous coal.

U.S. coal production in 1993 totaled 945 million short tons, the lowest level since 1987. Most of the production decline occurred in Appalachia, which bore the brunt of both a United Mine Workers of America (UMWA) strike and a decline in coal exports. West Virginia and Pennsylvania were the most severely affected with production drops of 20 percent and 13 percent, respectively. Coal production in the Western Region in 1993 rose 7 percent above the 1992 level to 369 million short tons. The average mine price of coal fell for the 11 th consecutive year to $\$ 19.85$ per short ton.

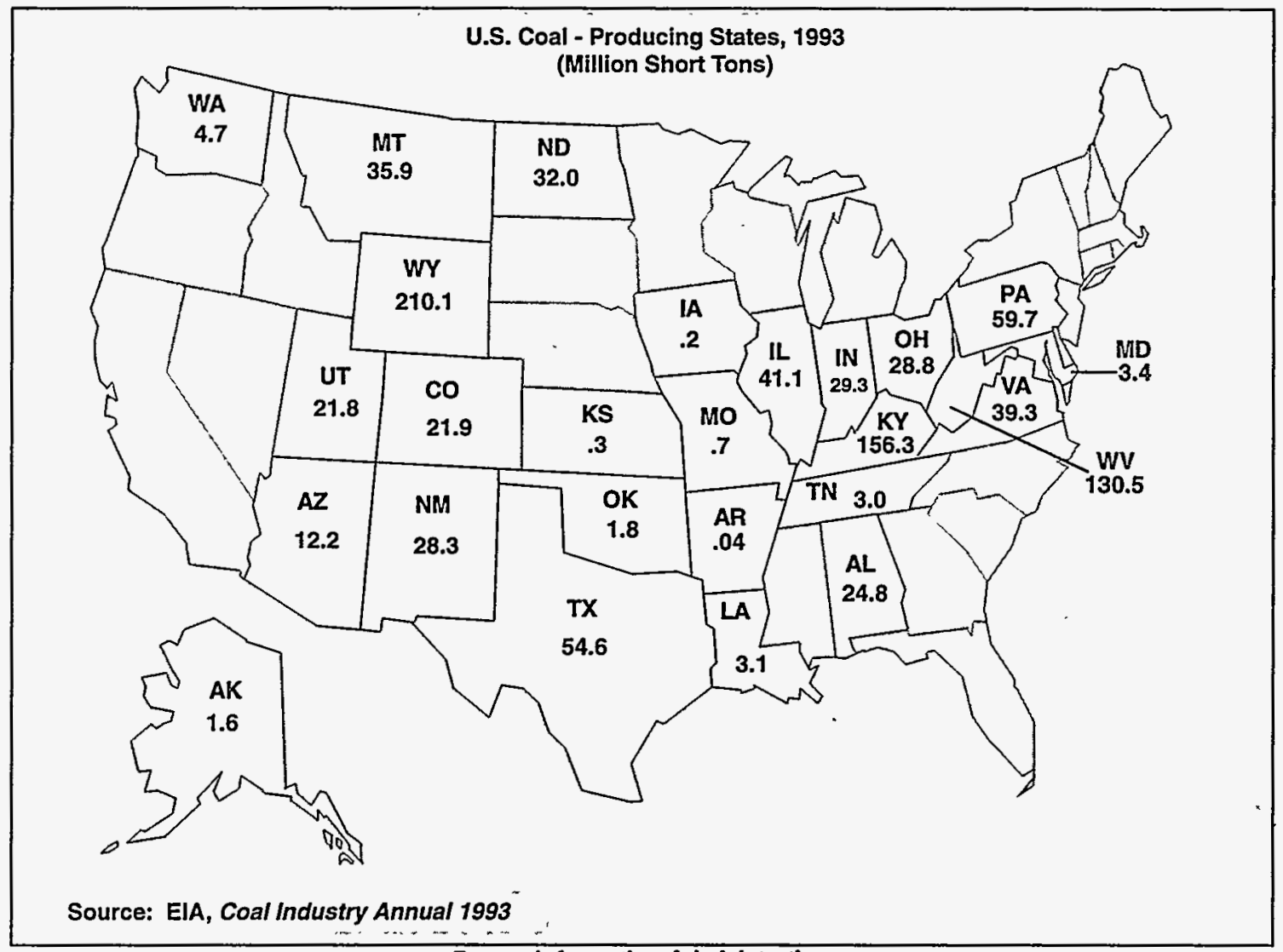

Energy Information Administration 
In 1993, Wyoming was the Nation's leading coal-producing State with production of 210 million short tons, which was about 22 percent of the national total. Kentucky ranked second, with 156 million short tons (17 percent), and West Virginia was third, with 131 million short tons (14 percent). Together, these three States accounted for 53 percent of total U.S. coal production.

There were 196 mines in 1993 that produced 1 million or more short tons. They produced 67 percent of the total national production, although they represented only 8 percent of active mines. The Nation's largest coal mine, located in Campbell County, Wyoming, continued to be the Black Thunder Mine, with over 34 million short tons produced. Of the 196 large mines, 129 mines east of the Mississippi River produced about 222 million short tons, and 67 mines to the west of the Mississippi River produced 413 million short tons.

Productivity in 1993 reached 4.7 short tons per miner per hour. The average number of miners working daily fell to 101,322 .

Federal and Indian lands have become increasingly important sources of coal. The 286 million short tons produced from these lands in 1993 accounted for about 30 percent of the total U.S. coal output. Federal coal lands produced 258 million short tons in 10 States, and Indian coal lands yielded 28 million short tons in three States.

Preliminary numbers show that world coal production increased from 4.3 billion short tons in 1982 to 5 billion short tons in 1992. The major producers were China, the United States, and Russia. These three leading producers accounted for about 52 percent of the total 5 billion short tons produced in 1992 .

More information on this subject can be found in the following EIA publications: Annual Energy Review; Weekly Coal Production; Coal Industry Annual; Coal Data: A Reference; Monthly Energy Review; and International Energy Annual. 


\section{Coal Prices}

In the early 1900's, coal was the Nation's major fuel source, supplying almost 90 percent of its energy needs. Later, coal's importance declined, mainly because petroleum and natural gas were cost effective and efficient. However, at the present time, coal is the primary source used for electricity generation because it is now far cheaper than other fossil fuels and is also more abundant in the United States. Over 80 percent of the coal produced in the United States in 1993 was delivered to domestic power plants. Of the total coal consumed in the United States, 88 percent was used for generating electricity--accounting for 57 percent of the total electricity produced.

During the early 1970's, natural gas was the least expensive fuel used to generate electricity. In 1973 (the first year in which such data were recorded), electric utilities paid, on the average, about 34 cents per million Btu of natural gas, 41 cents per million Btu of coal, and 79 cents per million Btu of petroleum. Since 1976, however, coal has been the least expensive fossil fuel used to generate electricity. In 1993, on a dollars-per-million-Btu basis, natural gas was the most expensive fossil fuel (\$2.56), petroleum was second $(\$ 2.43)$, and coal was least expensive (\$1.39). Although these figures show that the cost of generating electricity from coal has increased significantly, it is still lower than the cost of generating electricity from either natural gas or petroleum.

Average Mine Price of U.S. Coal, 1983-1993

$\begin{array}{cc}\text { Year } & \text { Dollars per Short Ton } \\ 1983 & 25.98 \\ 1984 & 25.61 \\ 1985 & 25.20 \\ 1986 & 23.79 \\ 1987 & 23.07 \\ 1988 & 22.07 \\ 1989 & 21.82 \\ 1990 & 21.76 \\ 1991 & 21.49 \\ 1992 & 21.03 \\ 1993 & 19.85\end{array}$

Factors affecting the quantity, quality, and cost of coal delivered to the electric utilities in 1993 were a lengthy coal miners strike, extreme weather conditions, the availability of nuclear- and hydro-powered electric generation, and a reduction in coal stocks. The average spot-market price for coal delivered to the electric utilities reflected the impact of the coal strike (in June 1993, the delivered spot-market price for coal was $\$ 26.26$ and in October, the spot-market price was $\$ 29.28$ ). Weather conditions affected the delivery of coal because of severe flooding along the Mississippi and Missouri Rivers. 
The average coal export price for 1993 was $\$ 41.41$ per short ton. Coal exports in 1993 totaled 75 million short tons, a 27-percent decrease from 1992 and the lowest level since 1979. The primary reasons for the decline were reduced demand for steam coal by Canada and reduced demand for both metallurgical and steam coal by European countries. The total coal imports for 1993 rose to a record annual level of 7.3 million short tons, 92 percent more than 1992. The average coal import price for 1993 was $\$ 29.89$ per short ton.

Another important use of coal is to produce coke, which is used in smelting iron ore to make steel. The average price paid for the special type of coal used to make coke generally declined in the early 1980's. From 1991 to 1993 , it decreased from $\$ 48.88$ per short ton to $\$ 47.44$ per short ton.

The average mine price per short ton of coal in 1993 was $\$ 19.85$. This was a drop of 6 percent from 1992 and the 11th straight year of decline. Because coal is so abundant, and as long as it remains relatively low priced, power plants will continue to use it rather than the two other major fossil fuels-petroleum and natural gas--to generate electricity.

More information on this subject can be found in the following EIA publications: Cost and Quality of Fuels for Electric Plants; Electric Power Monthly; Coal Industry Annual; Quarterly Coal Report; and Coal Data: $A$ Reference. 


\section{Coal Demand}

During 1993, a total of 925.9 million short tons of coal was consumed in the United States. The greatest demand for coal was by electricity generating plants that burn coal to produce electricity. In $1993,813.5$ million short tons were used by electric utilities, accounting for 88 percent of coal consumed in the United States. About 57 percent of the electricity generated was by coal-fired plants. Each ton of coal consumed at an electric power plant produces about 2,000 kilowatthours of electricity. A pound of coal supplies enough electricity to light 10100 -watt bulbs for about an hour.

The second largest sector of coal demand was for industrial use. Industrial use of coal amounted to 74.9 million short tons in 1993. Some industries that used coal included cement, chemicals, paper, and primary metals. Cement plants use about a ton of coal for each 3.5 tons of cement produced. Small amounts of coal are also used to manufacture a number of everyday products such as photographic film base, carbon and graphite electrodes, varnishes, perfumes, dyes, plastics, paints, and inks.

Demand for U.S. Coal, 1993

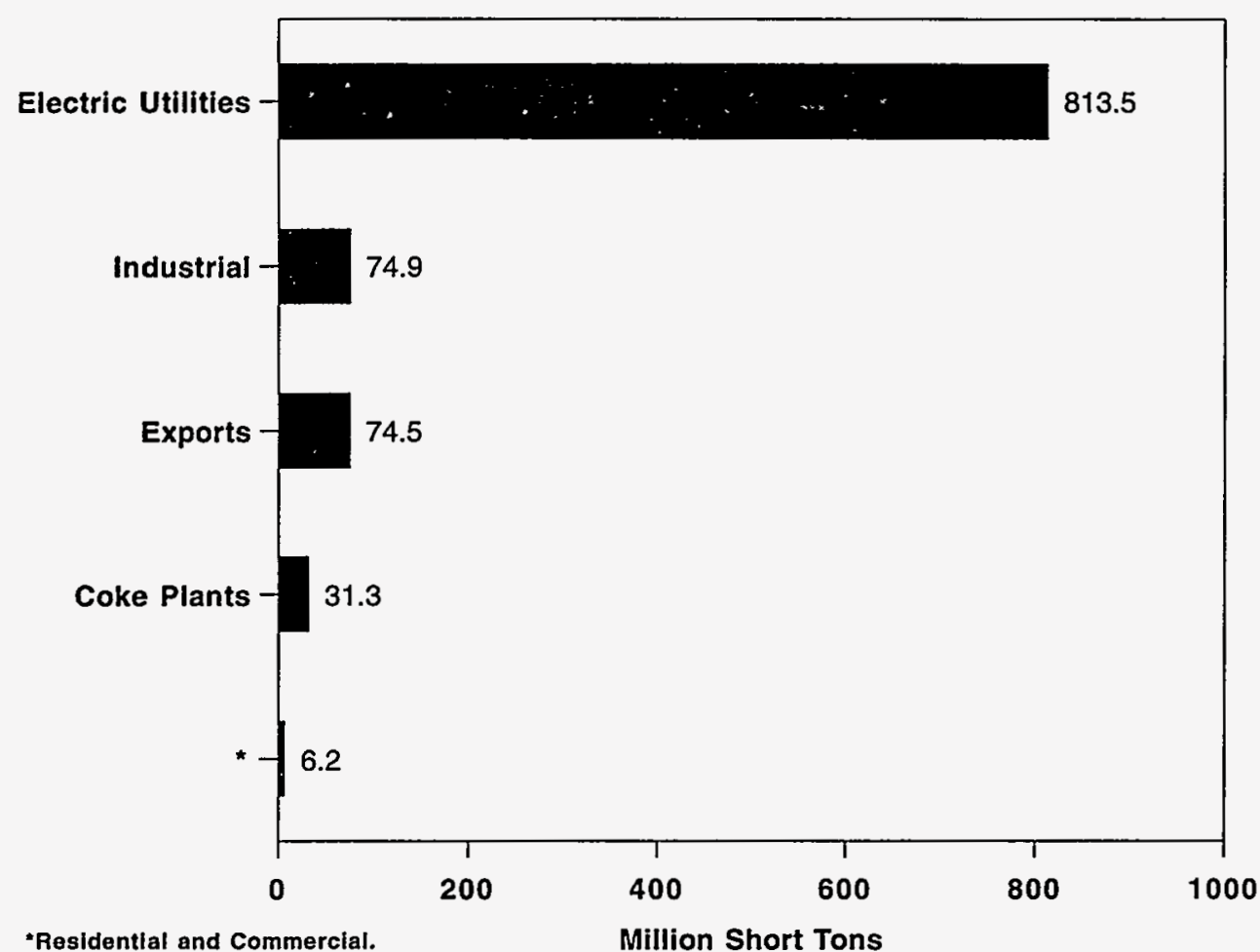

Source: Energy Information Administration, Annual Energy Review 1993, DOE/ElA-0384(93)(Washington, DC, July 1994).

Coal exports in 1993, about 8 percent of demand, totaled 74.5 million short tons, a 27 -percent decrease from 1992 and the lowest level since 1979. The primary reasons for the decline were reduced demand for steam coal by Canada and reduced demand for both metallurgical and steam coal by European countries. The leading destinations for U.S. coal exports were Japan, Canada, Italy, the Netherlands, and Brazil, together accounting for 52 percent of the total. The Customs District of Norfolk, Virginia, handled 50 percent of all coal exported during 1993. 
In 1993, 31.3 million short tons were consumed by coke plants. Through a process known as "carbonization," coal is converted into coke. Coke is then used in smelting iron ore to produce steel. Both the number of coke plants and the amount of coal carbonized have declined since 1973. There are presently about half as many coke plants as there were a decade ago. The residential and commercial sectors consumed a small percentage of coal for building heating, using 6.2 million short tons in 1993.

Over 530 million short tons of coal transported within the United States in 1993 were moved by rail. River barge shipping in the inland waterways system was the next most prevalent mode, carrying over 122 million short tons. Slightly more coal was shipped by truck than was carried by tramway, conveyors and coal slurry pipeline. The Nation's only coal slurry pipeline, the 273-mile-long Black Mesa line, carries about 5 million tons of coal annually. The slurry is composed of half water and half finely ground coal and delivers coal from a mine in Arizona to a power plant in southern Nevada.

Texas led all States in coal consumption in 1993, using 96.8 million short tons. Indiana and Ohio were second and third, respectively. These three States accounted for almost a quarter of the total U.S. coal consumption for the year. Ranked 10th in coal use, North Dakota is the site of one of three operating coal gasification plants in the United States. These plants use coal to produce natural gas. The Dakota Gasification Company uses 18,000 tons of lignite per day to produce about 162 million cubic feet per day of synthetic natural gas. The other two operating gasification plants are in Louisiana and Tennessee.

Coal Consumption, 1993

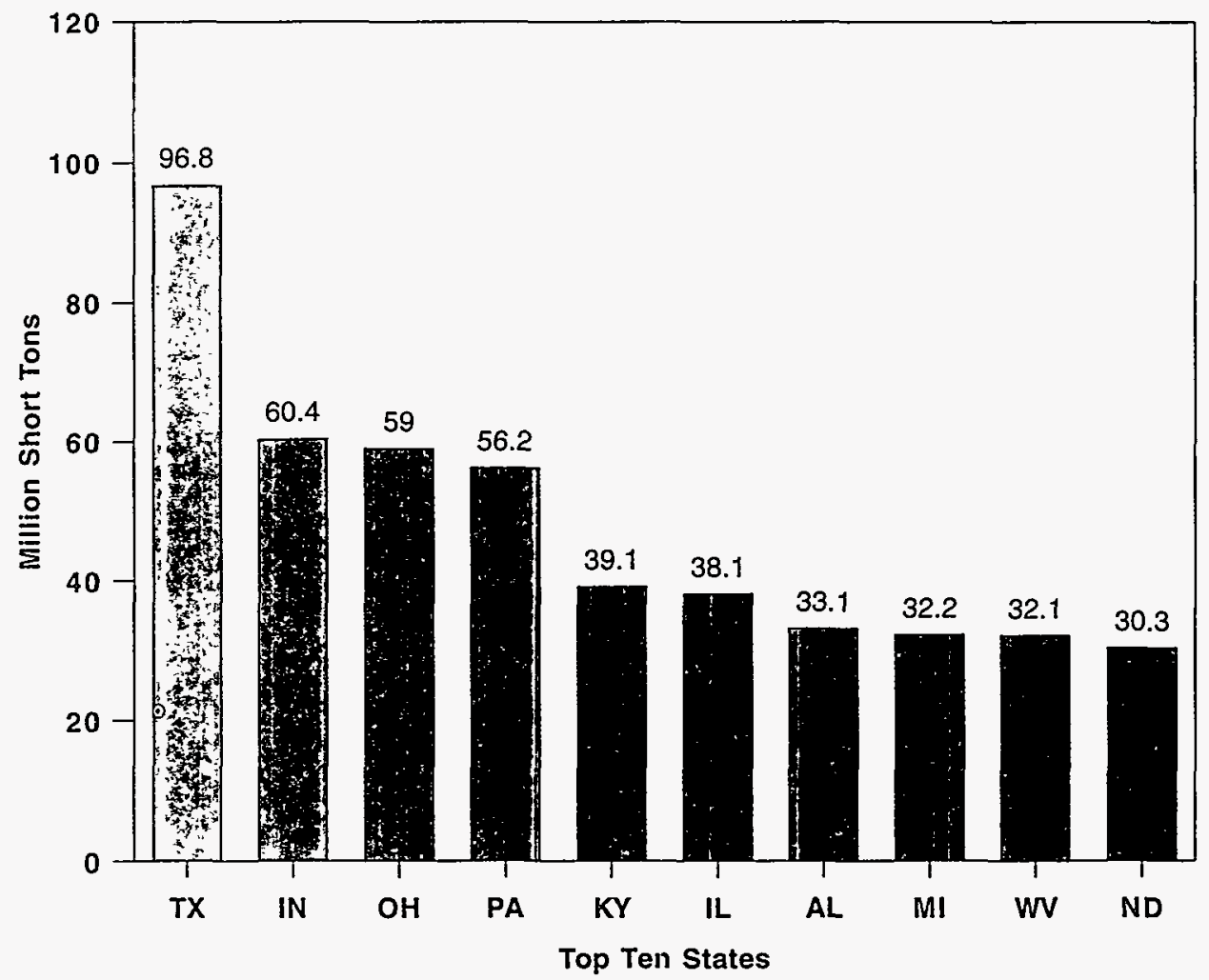

Source: Energy Information Administration, Quarterly CoalReport April-June 1994, DOE/EIA-0121(94/20)(Washington, DC, December 1994).

More information on this subject can be found in the following EIA publications: Coal Industry Annual; Quarterly Coal Report; Coal Data: A Reference; and Monthly Energy Review. 


\section{Coal Reserves}

In the United States, there are vast deposits of coal--more extensive than those of natural gas and petroleum, the other major fossil fuels. If total estimated recoverable reserves of the major fossil fuels are compared on the basis of heat content, about 3 percent of reserves are crude oil, about 4 percent are natural gas, and over 90 percent are coal.

Total U.S. coal resources in the ground are estimated to be 4 trillion tons, of which 1.7 trillion tons are identified resources. Identified resources include the demonstrated reserve base (DRB), which comprises coal resources that have been mapped within specified levels of reliability and accuracy and which occur in coal beds meeting minimum criteria of thickness and depth from the surface generally required for economic mining under current technologies. As of January 1, 1993, the U.S. DRB contained an estimated 474 billion short tons. Because of property rights, land use conflicts, and physical and environmental restrictions, some coal in the DRB may not be available and accessible for mining.

The actual proportion of minable coal resources that can be recovered from undisturbed deposits varies from less than 40 percent in some underground mines to more than 90 percent at some surface mines. In some underground mines, much of the coal may be left untouched as pillars needed to prevent surface collapse. EIA's most recent estimate assumes that nearly 56 percent of the DRB may be recoverable. Geologic features, such as folding, faulting, and interlayered rock strata, can mean a reduction in the amount of coal that can be recovered at both underground and surface mines. Currently, it is estimated that U.S. recoverable coal reserves total 261 billion short tons.

There are four recognized ranks of coal in the U.S. classification scheme: anthracite, bituminous, subbituminous, and lignite. In the United States, coal rank is classified according to its heating value, its fixed carbon and volatile matter content, and, to some extent, its agglomerating characteristics (or caking properties during combustion). Of the four ranks, bituminous coal accounts for over half (51 percent) of the DRB. Bituminous coal is concentrated primarily east of the Mississippi River, with the greatest amounts in Illinois, Kentucky, and West Virginia. All subbituminous coal (38 percent of the DRB) is west of the Mississippi River, with most of it in Montana and Wyoming. Lignite, the lowestrank coal, accounts for about 9 percent of the DRB and is found mostly in Montana, Texas, and North Dakota. Anthracite, the highest-rank coal, makes up less than 2 percent of the DRB and is concentrated almost entirely in northeastern Pennsylvania.

Current world recoverable reserves are estimated to be 1.1 trillion short tons. It is estimated that the United States possesses nearly one-fourth of the world's recoverable coal reserves, about the same as the former Soviet Union. China (16 percent), Australia ( 9 percent), Germany ( 7 percent), South Africa (5 percent), and Poland (4 percent) also have significant amounts of recoverable coal reserves.

In 1990, EIA held the Coal Reserves Assessment Conference, which led to a plan for improving coal reserves data. That plan was embodied in the Coal Reserves Data Base (CRDB) program initiated later that year to help meet the growing need for updated data on U.S. coal reserves. That program has encouraged the strong participation of State agencies in revising resource estimates of coal reserves in those States. 
More information on this subject can be found in the following EIA publications: U.S. Coal Reserves: An Update by Heat and Sulfur Content; Coal Data: A Reference; International Energy Annual; Coal Industry Annual; Annual Energy Review; and the British Petroleum Corporation's Statistical Review of World Energy (London, England, June 1990). 


\section{Natural Gas Production}

Natural gas, a combustible gaseous mixture of hydrocarbons, mostly methane, is produced from wells drilled into underground reservoirs of porous rock. When the gas is first withdrawn from the well, it may contain liquid hydrocarbons and nonhydrocarbon gases. The natural gas is separated from these components near the site of the well or at a natural gas processing plant. The gas is then considered "dry" and is sent through pipelines to a local distribution company, and, ultimately, to the consumer.

In 1993, dry natural gas production accounted for 29 percent of total U.S. energy production and was produced from over 280,000 wells located in 33 of the 50 States and in Federal waters in the Gulf of Mexico and off the coast of California. Out of total U.S. production of 18.4 trillion cubic feet (Tcf), Texas led all States with 5.9 Tcf, followed by Louisiana with 5 Tcf and Oklahoma with 1.9 Tcf.

\section{U.S. Dry Natural Gas Production, 1973-1993}

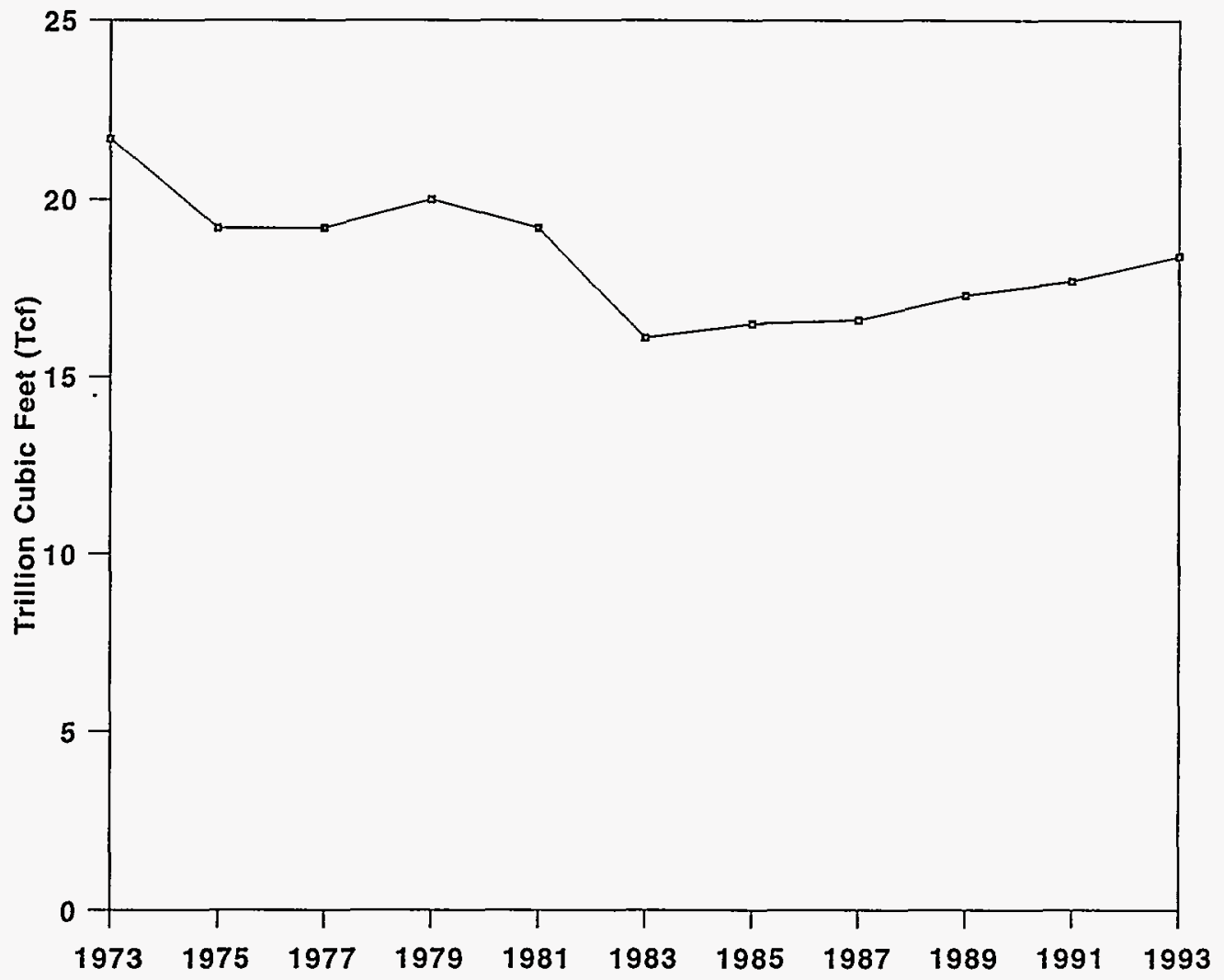

Source: Energy Information Administration, Monthly Energy Review, DOE/EIA-0035(94/04)(Washington, DC, April 1994).

After reaching a peak of $21.7 \mathrm{Tcf}$ in 1973, U.S. production declined as low as $16.1 \mathrm{Tcf}$ in 1986 . Since then, production has increased each year except 1991 . By the year 2000 , production is expected to range between 19 Tcf and 21 Tcf.

In addition to natural gas production, the U.S. gas supply is augmented by imports from Canada and Algeria, and by supplemental gaseous fuels. Supplemental gas supplies, which in 1993 totaled 119 billion 
cubic feet (Bcf), include refinery gas, propane-air mixtures, and synthetic natural gas, which is manufactured from petroleum hydrocarbons or from coal. The single largest source of synthetic gas is the Great Plains Synfuels Plant in Beulah, North Dakota, which in 1993 produced 58 Bcf of gas from coal.

Imports of natural gas in 1993 totaled $2.4 \mathrm{Tcf}$, or over 11 percent of total U.S. consumption. The vast majority of these imports, about 2.3 Tcf, arrive from Canada via pipeline. Gas imported from Algeria, 82 Bcf in 1993, is first cooled to -260 degrees Fahrenheit at which point the gas becomes a liquid. (As a liquid, over 600 cubic feet of natural gas can occupy the same amount of space that one cubic foot of natural gas would at standard conditions.) The liquefied natural gas (LNG) is then transported to the United States on specially designed ships.

Worldwide production of natural gas is dominated by the United States and Russia, whose combined production accounted for over 53 percent of the $75 \mathrm{Tcf}$ produced in 1992.

More information on this subject can be found in the following EIA publications: Monthly Energy Review, Natural Gas Annual, International Energy Annual, and Annual Energy Outlook. 


\section{Natural Gas Prices}

The Natural Gas Policy Act of 1978 (NGPA) mandated the phased decontrol of the wellhead price of "new gas" supplies (generally natural gas from wells drilled after 1976) and continued price control of "old gas" (generally natural gas dedicated to interstate commerce prior to enactment of the NGPA) and certain categories of incentive-priced natural gas. On January 1, 1985, new natural gas prices were decontrolled pursuant to the NGPA. Certain additional volumes of new onshore production were decontrolled on July $1,1987$.

On July 26, 1989, the President signed legislation to remove all remaining natural gas wellhead price controls by 1993. This action was significant, particularly for an industry that historically has been subject to extensive regulation. It continues the trend toward increased operation of free market forces in the natural gas industry. To allow ample time for contracts to be renegotiated, Congress adopted a phase-in schedule for decontrol. In general, price controls will be eliminated when current contracts between producers and buyers expire. All natural gas covered by expired, terminated, or new contracts signed after enactment of the bill was immediately decontrolled. Natural gas produced from any wells drilled after enactment of the bill was decontrolled on May 15, 1991. On January 1, 1993, all price controls on the first sale of natural gas were removed.

\section{Average Price of Natural Gas Delivered to U.S. Customers, 1973-1993}

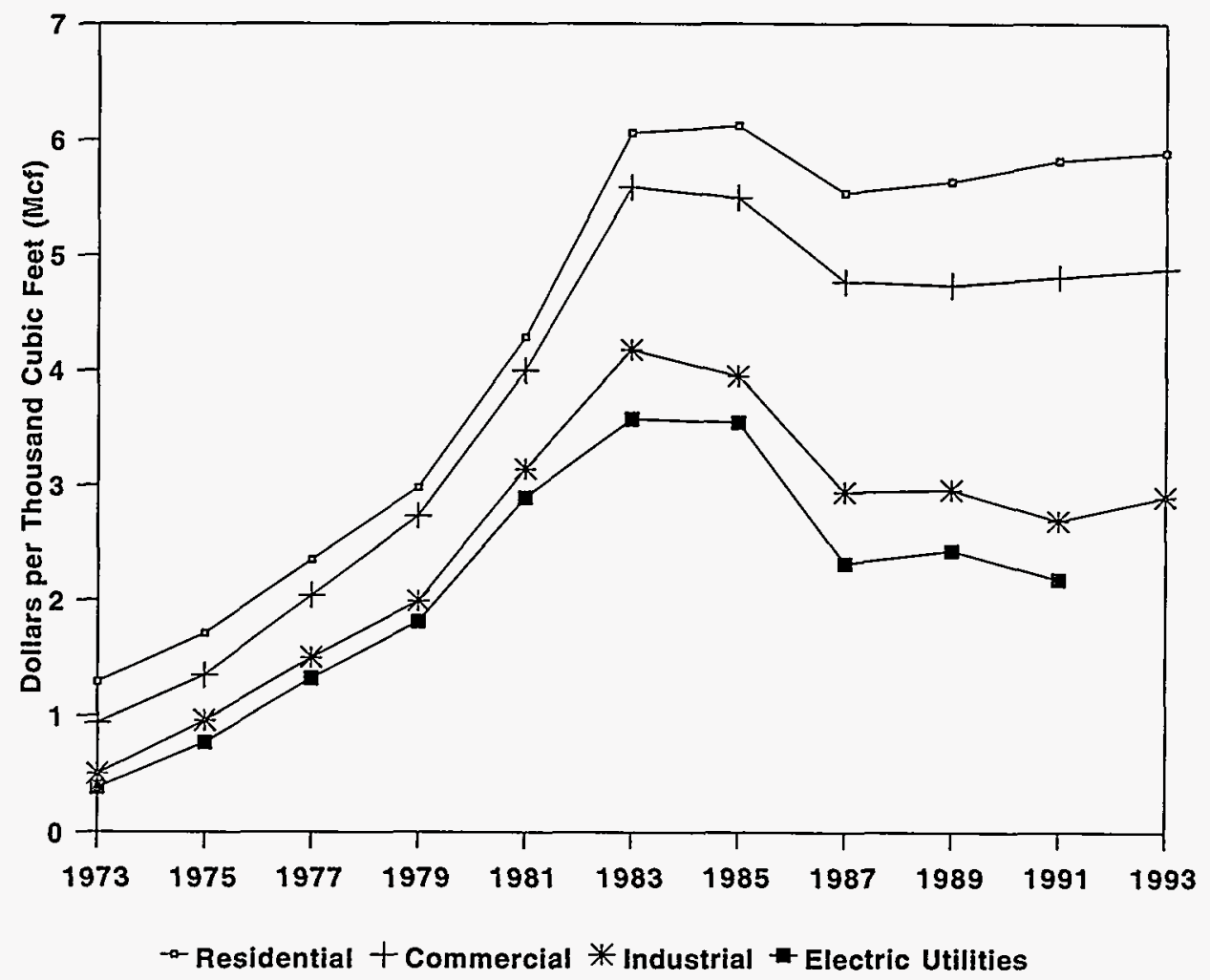

Source: Energy Information Administration, Annual Energy Review 1993, DOE/EIA-0384(93)(Washington, DC, July 1994). 
In April 1992, the Federal Energy Regulatory Commission (FERC) issued Order 636 which restructured the interstate pipeline industry. Interstate pipeline companies were required to separate (or "unbundle") all of their services. Gas purchases are essentially free from regulation, while transportation and storage remain subject to FERC jurisdiction. Costs associated with the restructuring of the natural gas industry will continue to affect consumer prices through 1998. These costs include take-or-pay settlement costs and the general transition costs of Order 636. Natural gas markets are becoming less and less regulated, however, the end-use markets are still generally under the control of the various State utility commissions.

Natural gas is extracted from the ground by a producing company. From the well, it may go to a gas processing plant for removal of liquid hydrocarbons, sulfur, carbon dioxide or other components which naturally occur with the methane. Next a pipeline carries the gas to a local distribution company. The local distribution company, in turn, delivers the natural gas to the end user. A large end user may purchase the natural gas directly from a producer, a natural gas broker or marketer, or a pipeline company. In any event, in most cases, the gas is physically delivered through the pipeline system to the local distribution company and then to the customer.

The average price of natural gas is different for the four end-use sectors: residential, commercial, industrial, and electric utilities. Some of the major factors that influence the end-use sector prices are the amount of natural gas sold, the distribution costs, and the price of competing fuels. During 1973, the critical year of the Arab oil embargo, the residential sector paid an average price of $\$ 1.29$ per thousand cubic feet; the commercial sector, 94 cents per thousand cubic feet; the industrial sector, 50 cents per thousand cubic feet; and the electric utilities, 38 cents per thousand cubic feet.

During 1993, the residential sector remained the highest paying sector, its price averaging $\$ 6.16$ per thousand cubic feet. The average commercial sector price was $\$ 5.16$ per thousand cubic feet, the industrial sector price was $\$ 3.09$ per thousand cubic feet, and the electric utilities sector price was $\$ 2.61$ per thousand cubic feet.

More information on this subject can be found in the following EIA publications: Natural Gas Annual, Natural Gas Monthly, and Natural Gas Issues and Trends. 


\section{Natural Gas Consumption}

Natural gas is best known as the fuel that produces the blue flame that heats our food, our water, and our homes and buildings. It is also used to generate electricity, provide heat for industrial processes, and is used as a raw material to produce petrochemicals.

For centuries, natural gas has been used in various parts of the world. The Chinese, 2,000 years ago, piped natural gas through bamboo poles from shallow wells. They then burned the gas to heat large pans to evaporate sea water for salt. It is believed that the first commercial use of natural gas in the western world was for street lighting in Genoa, Italy, in 1802.

In 1993, U.S. natural gas consumption was over 20 trillion cubic feet (Tcf), which was about 25 percent of all U.S. energy consumption. Industrial sector consumption was $7.9 \mathrm{Tcf}$, or 39 percent of total gas consumption. Residential sector consumption was $5 \mathrm{Tcf}, 24$ percent of the total, and commercial sector consumption was $2.9 \mathrm{Tcf}, 14$ percent. Electric utilities, which burned $2.7 \mathrm{Tcf}$ of gas to generate electricity, accounted for 13 percent of total gas consumption. In addition, $1.8 \mathrm{Tcf}$, or 9 percent of the total, was used in producing, processing, and transporting natural gas. By the year 2010, U.S. natural gas consumption is projected to range between $23 \mathrm{Tcf}$ and $25 \mathrm{Tcf}$, with most of the increase being used for electricity generation.

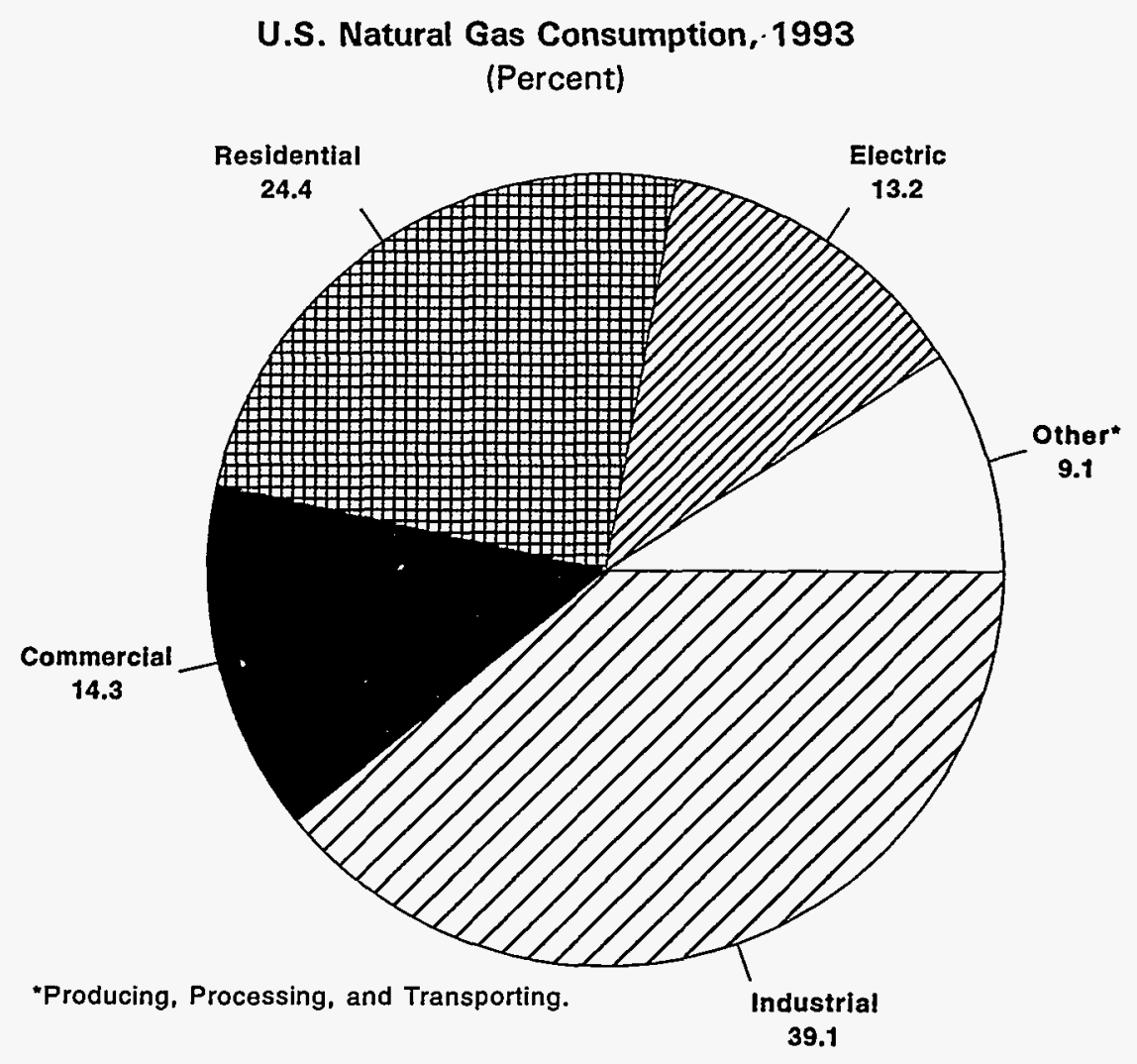

Source: Energy Information Administration, Natural Gas Monthly, DOE/EIA-0130(94/10)(Washington, DC, October 1994). 
In 1992, world natural gas consumption was 74.7 Tcf. Russia, which consumed $16.1 \mathrm{Tcf}$, and the United States, which consumed 19.8 Tcf, accounted for 48 percent of the total. By the year 2010 , total world consumption is expected to range between 103 Tcf and 126 Tcf.

More information on this subject can be found in the following EIA publications: Monthly Energy Review, Natural Gas Monthly, Natural Gas Annual, International. Energy Annual, Annual Energy Outlook, and International Energy Outlook. 


\section{Natural Gas Reserves}

The most common theory about how natural gas was created holds that it was formed by the underground decomposition of organic matter (dead plants and animals). If the organic matter is buried deeply enough, much of the carbon and hydrogen is converted to methane, the major component of natural gas. (The chemical formula for methane is $\mathrm{CH}_{4}$-that is, one molecule of methane contains one carbon atom and four hydrogen atoms.) Large volumes of methane have been subsequently trapped in the subsurface of the Earth at places where the right geological conditions occurred at the right times. Such a place is called a reservoir.

Proved reserves of natural gas are estimated quantities that analyses of geological and engineering data have demonstrated to be economically recoverable in future years from known reservoirs. The natural gas placed in underground storage is not included in proved reserves. It is not necessary that production, gathering, or transportation facilities be actually installed or operative for a reservoir to be considered proved. It is assumed that production will be initiated if and when economically justified.

As of December 31, 1993, the estimated U.S. total proved reserves, wet after lease separation, were 170,490 billion cubic feet (Bcf). ("Wet after lease separation" is the term used to describe the volume of natural gas remaining after removal of lease condensate, a mixture consisting primarily of pentanes and heavier hydrocarbons.) Of those $170,490 \mathrm{Bcf}$, non-associated gas (natural gas not in contact with significant quantities of crude oil) accounted for 140,445 Bcf. The remaining natural gas occurred with crude oil, either as free gas (associated) or in solution with crude oil (dissolved), and accounted for 30,045 Bcf. Estimated proved reserves of dry natural gas in the United States were 162,415 Bcf. (Dry

\section{U.S. Dry Natural Gas Proved Reserves}

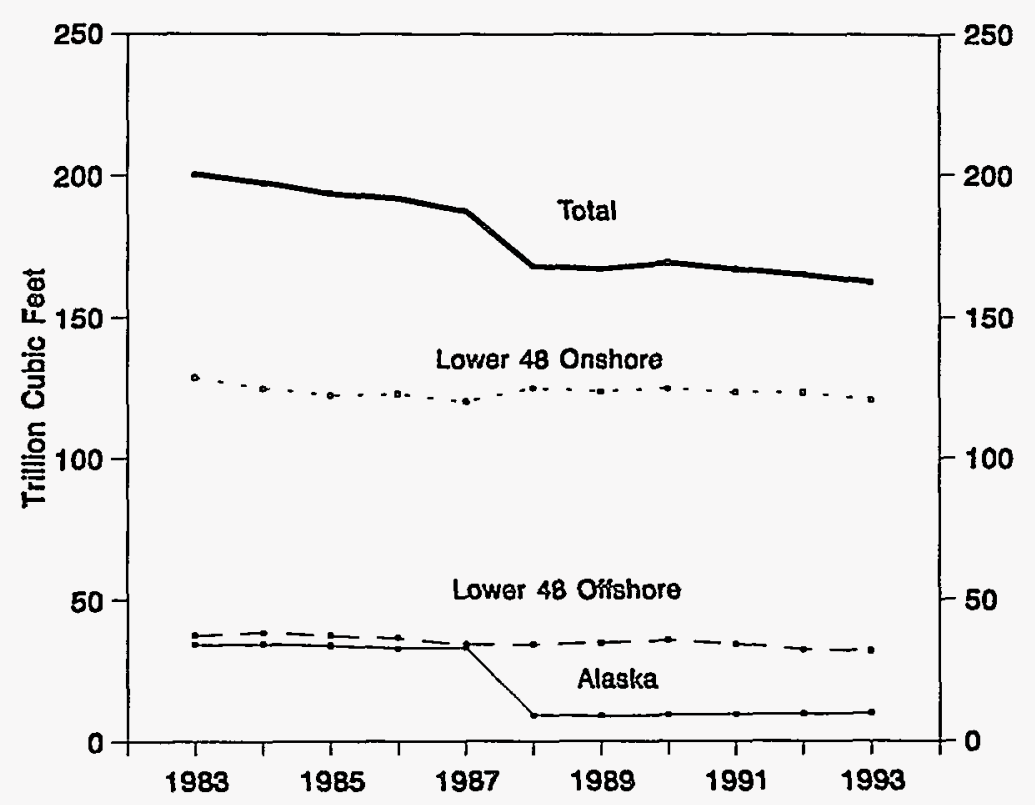

Source: Energy Information Administration, U.S. Crude Oil, Natural Gas, and Natural Gas Liquids Reserves, DOE/EIA0216(93)(Washington, DC, October 1994). 
natural gas is the volume of natural gas that remains after the economically liquefiable hydrocarbon portion has been removed from the gas stream at a natural gas processing plant.) Dry natural gas reserves decreased 1.6 percent in 1993, a loss of 2,600 Bcf. Coalbed methane accounted for over 6 percent of reserves and 4 percent of production in 1993.

In addition to proved natural gas reserves there are large volumes of natural gas classified as undiscovered recoverable resources. Those resources are expected to exist because the geologic settings are favorable. Over half of all onshore undiscovered gas resources are located in the Alaska and Gulf Coast regions. Over one-third of all undiscovered gas resources are estimated to be in Federal offshore areas, primarily near Alaska, in the Gulf of Mexico, and along the Atlantic Coast.

More information on this subject can be found in the following EIA publications: U.S. Crude Oil, Natural Gas, and Natural Gas Liquids Reserves and Annual Energy Review. 


\section{Electricity Generation}

Consumers expect electricity to be available whenever they plug in an appliance, turn a switch, or open a refrigerator. Satisfying these instantaneous demands requires an uninterrupted flow of electricity. In order to meet this requirement, utilities operate several types of electric generating units, powered by different fuel sources: coal, uranium, water, natural gas, petroleum, and nonwater renewable energy sources.

Steam-electric generating units burn fossil fuels such as coal, natural gas, and petroleum. The steam turns a turbine that produces electricity through an electrical generator. Natural gas and petroleum are also burned in gas turbine generators where the hot gases produced from combustion are used to turn the turbine, which in turn spins the generator to produce electricity. Additionally, petroleum is burned in generating units with internal-combustion engines. The combustion occurs inside cylinders of the engine, which is connected to the shaft of the generator. The mechanical energy provided from the engine drives the generator to produce energy.

Coal was the fuel used to generate the largest share (57 percent) of electricity in 1993, 1,639 billion kilowatthours $(\mathrm{kWh})$. (This is over one and a half times the annual electricity consumption of all households in the United States (994 billion $\mathrm{kWh}$ ).) Natural gas was used to generate 259 billion $\mathrm{kWh}$ ( 9 percent), and petroleum accounted for 100 billion $\mathrm{kWh}$ ( 3 percent).

In nuclear-powered generating units, the boiler is replaced by a reactor in which the fission of uranium is used to make steam to drive the turbine. Nuclear generating units accounted for the second largest share (21 percent) of electricity generation in the United States in 1993, 610 billion $\mathrm{kWh}$.

U.S. Net Electricity Generation, 1993

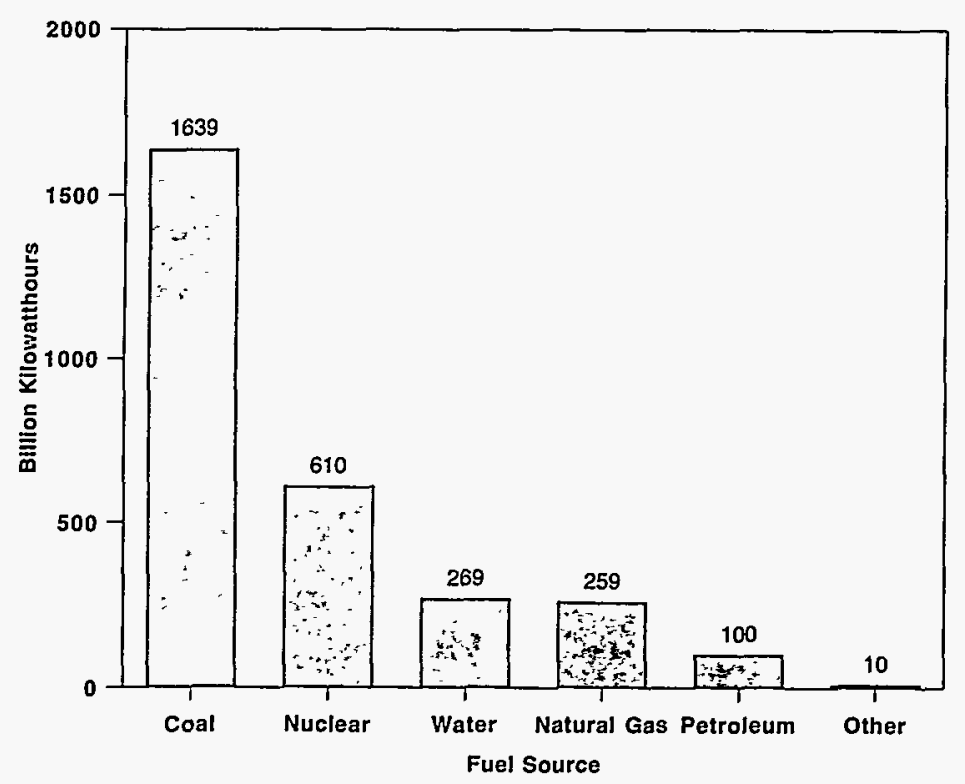

Source: Energy Information Administration, Annual Energy Review 1993, DOE/EIA-0384(93)(Washington, DC, July 1994). 
Hydroelectric power units use flowing water to spin a turbine connected to a generator. In a falling water system, water is accumulated in reservoirs created by dams, then released through conduits to apply pressure against the turbine blades to drive the generator. In a run-of-the-river system, the force of the river current applies the pressure to the turbine blades to produce electricity. In 1993, hydroelectric generation had the third largest share ( 9 percent) of electricity production at 269 billion $\mathrm{kWh}$.

Nonwater renewable sources of electricity generation presently contribute only small amounts (less than 1 percent) to total power production. These sources include geothermal, refuse, waste heat, waste steam, solar, wind, and wood. Electricity generation from these sources in 1993 totaled 10 billion $\mathrm{kWh}$.

Electric utility generation in 1993 was 2,882 billion $\mathrm{kWh}, 3$ percent greater than the 1992 total of 2,797 billion kWh.

More information on this subject can be found in the following EIA publications: Annual Energy Review, Electric Power Monthly, and Electric Power Annual. 


\section{Electricity Prices}

Electricity prices, or rates, are the fees an electric utility company charges its customers for service. An electric bill is computed on the basis of the individual customer's rate, the level of consumption, and other charges, such as taxes and fuel adjustments.

Electric utility companies charge their customers different rates, depending on the type of customer and on the customer's electricity needs. That collection of rates is called a tariff. The tariff is designed to provide the privately owned electric utility with enough income to allow investors to earn a cash return and cover operation and maintenance costs. Most of the larger utilities operate as regulated franchises, meaning that the prices they charge are subject to public review, often by a State public utility commission.

Publicly owned electric utilities are nonprofit, local government agencies established to provide service to their communities and nearby consumers at cost, returning excess funds to the consumer in the form of community contributions, more economic and efficient facilities, and lower rates. Publicly owned electric utilities (which number approximately 2,000 ) include municipals, public power districts, State authorities, irrigation districts, and other State organizations.

There are approximately 950 cooperative electric utilities in the United States currently doing business in 47 States. These utilities are owned by their members and are established to provide electricity to those members.

Average retail prices of electricity are calculated by dividing utility revenue by retail sales. The resulting measurement is the cost, or average revenue per kilowatthour, of electricity sold. (A kilowatthour is equal to 1 watt of power supplied to an electric circuit steadily for 1,000 hours.)

Average Retail Prices of Electricity, 1993

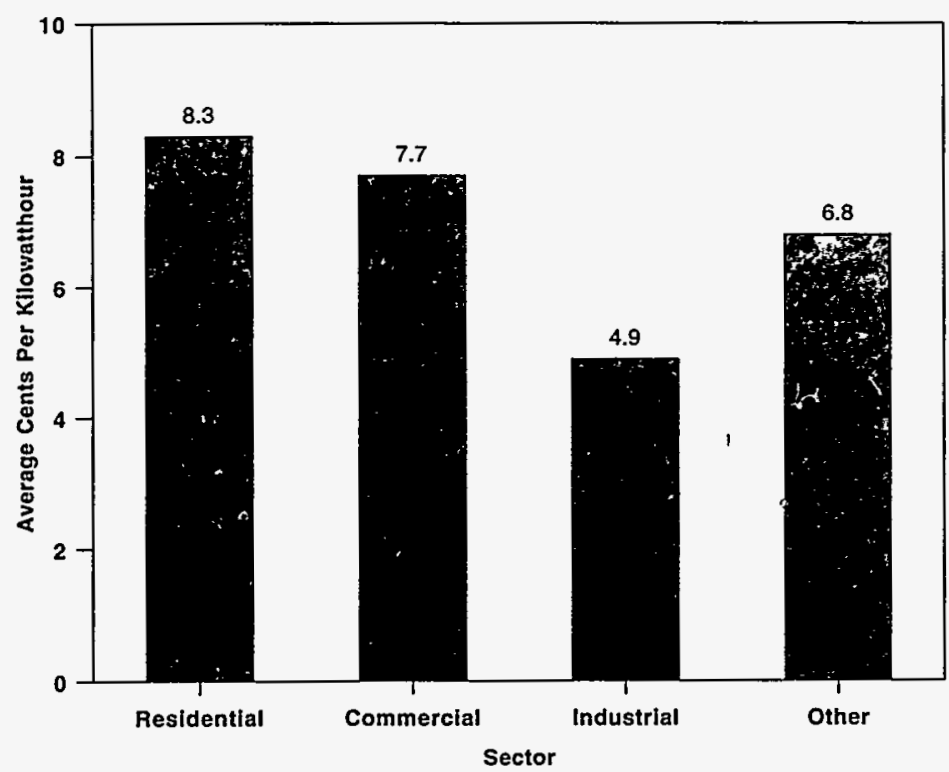

Source: Energy information Administration, Annual Energy Review 1993, DOE/EIA-0384(93)(Washington, DC, July 1994). 
Electric utilities usually offer three primary classes of service: residential, commercial and industrial. The average price per kilowatthour for residential consumers is generally higher than for any other sector due in part to higher costs associated with serving many consumers who use relatively small amounts of electricity. The industrial sector has the lowest rates due to the economies of serving a few consumers who use relatively large amounts of electricity.

Because of the type and availability of capacity and the cost of fuel, the average price for electricity differs across U.S. Census divisions. The New England and Middle Atlantic Census Divisions tend to have an average price that is higher than average because of their reliance on petroleum, whereas the East and West South Central Divisions rely on gas-fired generation and the East North Central and South Atlantic Divisions rely on coal-fired generation. Petroleum is generally a more expensive energy source than coal and natural gas. Because the Mountain Census Division relies on less expensive, locally mined coal, the price in this region is usually below the national average for all classes of consumers.

During the first half of the century, the national average price of electricity decreased as more efficient generating units were brought into service. This general trend has continued. The average real price of electricity to all sectors in 1993 (that is, the price adjusted to reflect the purchasing power of the dollar) was 14 percent below the price in 1960 . However, the apparent stability in electricity prices masked fluctuations that occurred throughout the period. For example, following the oil embargo in 1973 and 1974, electricity prices increased rapidly because of escalation in the costs of fuel, labor, materials, capital, and services to electric utilities.

More information on this subject can be found in the following EIA publications: Annual Energy Review, Electric Sales and Revenue, and Electric Power Annual. 


\section{Electricity Sales}

The electric utility industry began in 1882 with the establishment of Thomas Edison's power station in New York City. The use of electricity has been growing ever since. It is vital to virtually every aspect of our economy.

Electricity sales can be defined as the number of kilowatthours ( $1 \mathrm{kWh}=1,000$ watthours) sold during a given period. of time. Sales are normally classified according to the type of customer or service using the electricity, such as residential, commercial, industrial, transportation, and "other" which includes public street and highway lighting.

In 1993, U.S. electric utilities generated $2,882,525$ gigawatthours ( $1 \mathrm{GWh}=1$ billion watthours) of electricity and sold an estimated $2,862,279 \mathrm{GWh}$ to their consumers. This amount represents about a 2-percent increase over 1990 , when total sales were about $2,712,555 \mathrm{GWh}$. In 1973 , by contrast, total sales were $1,712,909 \mathrm{GWh}$.

Since 1980, sales to residential consumers have been increasing at an average rate of 2 percent per year. Residential consumers, in 1993, purchased $993,552 \mathrm{GWh}$, an increase of 3 percent over the amount purchased the previous year. The 1993 residential sales accounted for 34 percent of total sales. Among the nine Census divisions, the South Atlantic Division had the largest annual sales to residential consumers, both in $1992(219,372 \mathrm{GWh})$ and in $1991(218,512 \mathrm{GWh})$.

Since 1980, sales to commercial consumers have been increasing at an average annual rate of 4.2 percent. The South Atlantic Division realized the largest volume of commercial sales in $1992(159,131 \mathrm{GWh})$.

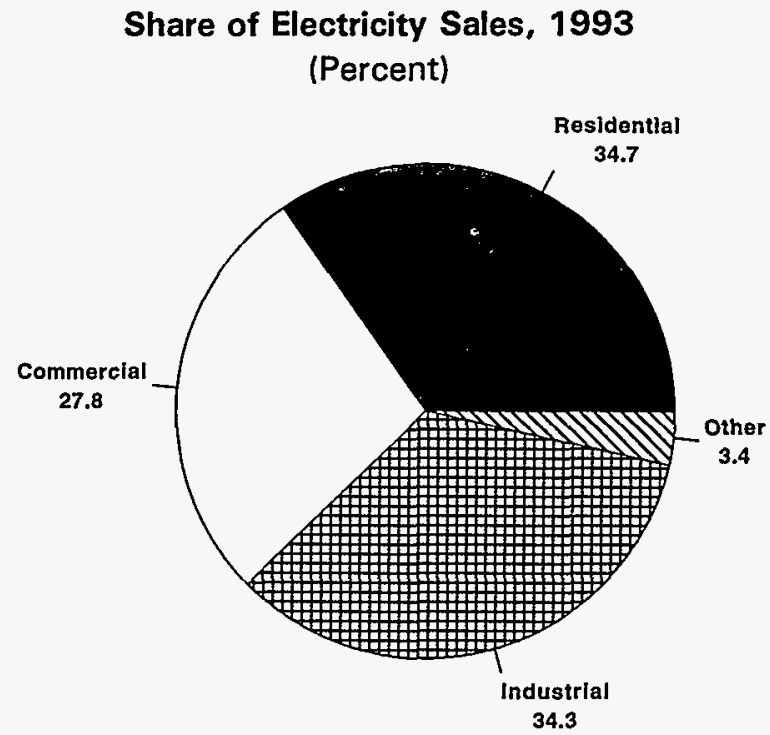

Source: Energy Information Administration, Annual Energy Review 1993, DOE/EIA-0384(93)(Washington, DC, July 1994), and Electric Sales and Revenue 1993, DOE/EIA-0540(93)(Washington, DC, January 1995). 
Industrial consumers in 1993 purchased 34 percent of sales to consumers, or $983,118 \mathrm{GWh}$, about 0.1 percent more than in 1992. Other sales (public street and highway lighting, sales to public authorities, and sales to railroads and railways) were $99,900 \mathrm{GWh}$, over 3 percent of total sales to all consumers and slightly more than the amount sold for similar purposes in 1992.

More information on this subject can be found in the following EIA publications: Electric Power Annual, Electric Power Monthly, and Annual Energy Review. 


\section{Electricity Capability}

The United States has the largest electrical system in the world, with over twice the generating capability of any other country. (Capability is a measure of the steady hourly output that a generating system is able to supply.) Electricity capability in the United States at the end of 1992 was 752 gigawatts (GW). (One gigawatt is equal to 1 million kilowatts, or slightly larger than the average capability of a nuclear reactor in the United States.) Of this total capability, $695 \mathrm{GW}$ were owned by utilities and $57 \mathrm{GW}$ were owned by nonutility sources such as industrial plants, independent power producers, and cogenerators (generating facilities that produce electricity and another form of useful thermal energy used for industrial, commercial, heating, or cooling purposes).

In order to meet the growing demand for electricity and to offset retirements of existing capacity, a projected $172 \mathrm{GW}$ of new capacity will be needed between 1990 and 2010. Of this amount, utilities are expected to add $110 \mathrm{GW}$ and nonutility producers (excluding cogenerators) $62 \mathrm{GW}$. These capacity needs are in addition to other means suppliers plan to meet the capacity needs. These include extending the service life of many existing units, repowering of existing capacity, more extensive utilization of existing capacity, growing purchases of power from cogenerators, and increased imports of electricity from Canada and Mexico. The amount of net electricity imports and purchases from nonutilities increased over 60 percent between 1990 and 1992, from 118 billion kilowathours (kWh) to 194 billion $\mathrm{kWh}$, accounting in 1992 for 6 percent of the electricity needed by utilities to meet customer demand. This degree of reliance is expected to double by 2010 , with the amount purchased from nonutilities increasing by over 150 percent between 1992 and 2010.

Renewable energy for electricity is dominated by hydropower, however, since the best resources for hydropower have already been developed, hydropower capacity is expected to increase only slightly. The contribution of other renewable resources, such as wind, solar, geothermal, municipal solid waste, and biomass, to electricity supply is projected to more than double by 2010 . Due to its lower cost and improved technology, and because ample wind resources are available in many regions, wind energy could experience the most growth, with development on a pilot basis occurring before 2005 .

While the United States has ample solar resources, the initial penetration of solar energy technologies will most likely be concentrated in the Southwest, where the resources are the best. Municipal solid waste electricity generation is a byproduct of waste management and its contribution to electricity supply will primarily be determined by waste disposal methods (the amount of recycling and waste minimization strategies employed) and related regulations. Geothermal energy is limited geographically to those areas with easily accessible high-temperature hydrothermal resources (hot water and steam). Biomass electricity generation by utility, independent, and industrial power producers is the largest single renewable category outside of hydroelectric power.

More information on this subject can be found in the following EIA publications: Annual Energy Outlook; Electric Power Annual; Commercial Nuclear Power: Prospects for the United States and the World; and World Nuclear Fuel Cycle Requirements. 



\section{Nuclear Power Generation}

Electricity has been generated by burning fossil fuels (coal, oil, and gas) since before the turn of the century. For over three decades, however, a nonfossil fuel, uranium, has also been used to produce electricity. The first nuclear power plant went into commercial operation in 1957 at Shippingport, Pennsylvania. Since then, the use of nuclear-generated electricity has grown substantially in the United States. By the end of 1993, there were 109 units in operation that produced 610 billion net kilowatthours, or 21.2 percent of total U.S. electricity generation.

Uranium occurs in nature in combination with small amounts of other elements. Economically recoverable uranium deposits have been discovered principally in the western United States, Australia, Canada, Africa, and South America. A ton of uranium ore mined in the United States yields about 7 pounds of uranium oxide $\left(\mathrm{U}_{3} \mathrm{O}_{8}\right)$. Uranium ore must be chemically processed, enriched, and formed into pellets before it can be used as a fuel.

Uranium fuel pellets are loaded into hollow tubes called fuel rods. Hundreds of fuel rods form fuel assemblies that, along with control rods, are placed into a nuclear reactor core and then submerged in water. Like fossil fuels, the resulting uranium fuel produces heat that turns water into steam. The steam turns blades in a turbine connected to an electrical generator. However, heat is produced differently in a nuclear reactor than in a fossil fuel power plant.

The nucleus of an atom consists of combinations of protons and neutrons--each of about equal weight. Energy in a nuclear reactor is derived from a process called nuclear fission, in which a neutron strikes the nucleus of a uranium atom and is absorbed. The absorption of the neutron makes the nucleus unstable, causing it to split into two atoms of lighter elements and release heat and new neutrons. The heat is used to produce electricity, while the neutrons can potentially be absorbed by other atoms of uranium, resulting in more nuclear fissions. This continuing process of fissioning is called a chain reaction. It is sustained because, for every atom of uranium fissioned by a neutron, new neutrons are released to continue the process.

The United States has more nuclear generating capacity than any other country in the world; next is France, third is Japan, and fourth is the Commonwealth of Independent States. Worldwide, growth in nuclear power has slowed and this trend is expected to continue. While no nuclear reactors have been ordered in the U.S. since 1978, several countries, notably France, Japan, and South Korea, continue to have ambitious nuclear construction programs. Concerns about issues such as high level waste disposal, decommissioning expenses when reactors are retired, and the use of nuclear reactors to relieve possible global warming associated with fossil-fuel based generation will influence the future level of growth of nuclear power worldwide. 
Operable Nuclear Units in the United States, 1993

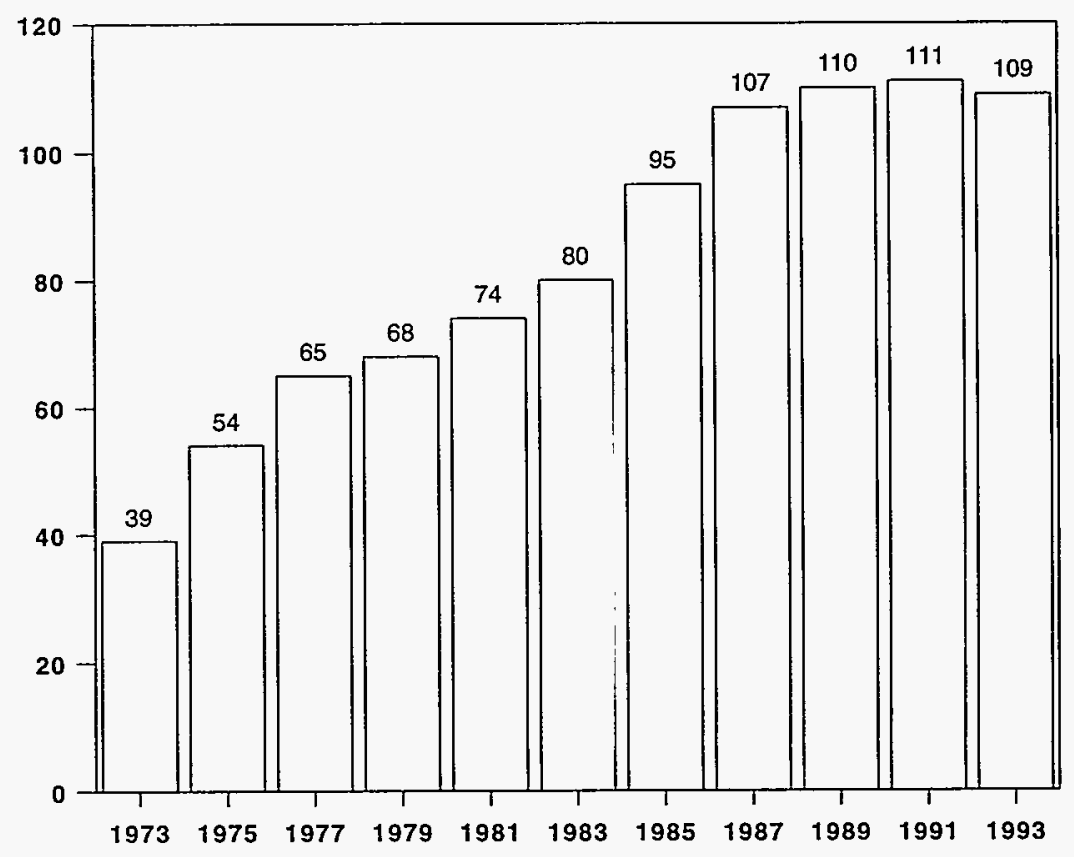

Source: Energy Information Administration, Annual Energy Review 1993, DOE/EIA-0384(93)(Washington, DC, July 1994).

More information on this subject can be found in the following EIA publications: Annual Energy Review, Electric Power Annual, and World Nuclear Fuel Cycle Requirements. 


\section{Renewable Energy}

While supplies of fossil fuels and uranium are limited and irreplaceable, renewable energy sources--such as the sun (solar), wind, water (hydropower), wood and other plant material (biomass), waste, and the heat of the earth (geothermal)--are practically inexhaustible or can be regenerated or recycled.

Some renewable energy sources, such as wood and other biomass, can be burned directly to provide heat for homes or fuel for boilers. Some biomass is converted to alcohol and used as automobile fuel. Solar collectors, which are often seen on rooftops, are used for space heating, hot water, and to heat swimming pools. All renewable energy sources, however, can be used to generate electricity. Among the renewable sources powering electricity generation, hydropower provides by far the largest contribution to United States energy supplies. In 1993, hydroelectric generation yielded about 269,098 gigawatthours (GWh) of electricity, 9 percent of all electricity generated in the country. (A watthour is a unit of electrical energy equal to 1 watt of power steadily supplied to or taken from an electric circuit for 1 hour. A gigawatthour equals a billion watthours.)

Other renewable sources--wood, waste, geothermal, wind, and solar--were responsible for about 69,000 GWh, representing about 2 percent of total generation. Nearly 85 percent of this electricity was generated by independent power producers and sold to electric utilities; the remaining 15 percent was generated by the utilities themselves.

The sun is expected to radiate energy at a fairly constant rate for a few billion years. The electromagnetic waves from the sun can be converted to other forms of energy, such as heat and electricity, which can be utilized by people. In order for solar energy to be used extensively, certain major problems must be dealt with. The sun does not shine steadily: when it is shining, it is not always at the same intensity; and some of the rays are bent or reflected by water droplets and dust particles in the atmosphere. The sun's rays have to fall on a relatively large area in order for enough usable energy to be collected. Where high temperatures are required, a "concentrating collector" can be used to focus the rays that fall on a large area onto a much smaller area.

The major economic applications of solar energy at present are for heating residences and other buildings. Solar energy can also be converted into usable electricity either by means of a photovoltaic cell (based on the element silicon) or by using solar radiation to heat a fluid which, in turn, drives a turbine connected to a conventional electric generator. In 1993, solar energy was used to produce about 780 gigawatthours of electricity.

The wind has been used as a source of energy for centuries. From 1880 to 1930, over 6 million windmills generated electric power in the western United States. The rising cost of fossil fuels, coupled with technological advances in windmill design, has made wind an attractive alternative energy source in the last decade. The western Great Plains and the New England and Pacific coastlines offer the most sustained usable wind velocities.

Wood and waste used by electric utilities for producing electricity include wood chips, sawdust, garbage, chemically inert gas, bagasse (plant refuse), and sewerage plant gas. Wood once supplied up to 90 percent of the energy needs of our country. In recent times, the demand for wood rose and fell with the 
price of fossil fuels. In 1993, wood and waste were used to generate over 50,000 gigawatthours of electricity.

Geothermal energy is heat generated by natural processes beneath the earth's surface. It is recovered as steam and hot water. The steam is harnessed to run generators. Most of the potential for using geothermal energy in the United States is in California, other far western States, and the Gulf Coast States. By far, the largest geothermal facilities now in operation are at the Geysers in northern California.

The use of renewable energy sources in the United States is not expected to approach that of the major energy sources in the near future. However, under appropriate conditions and for special purposes, renewable energy sources are proving to be of great value.

Renewable Energy Consumption Estimates, by Use, 1992

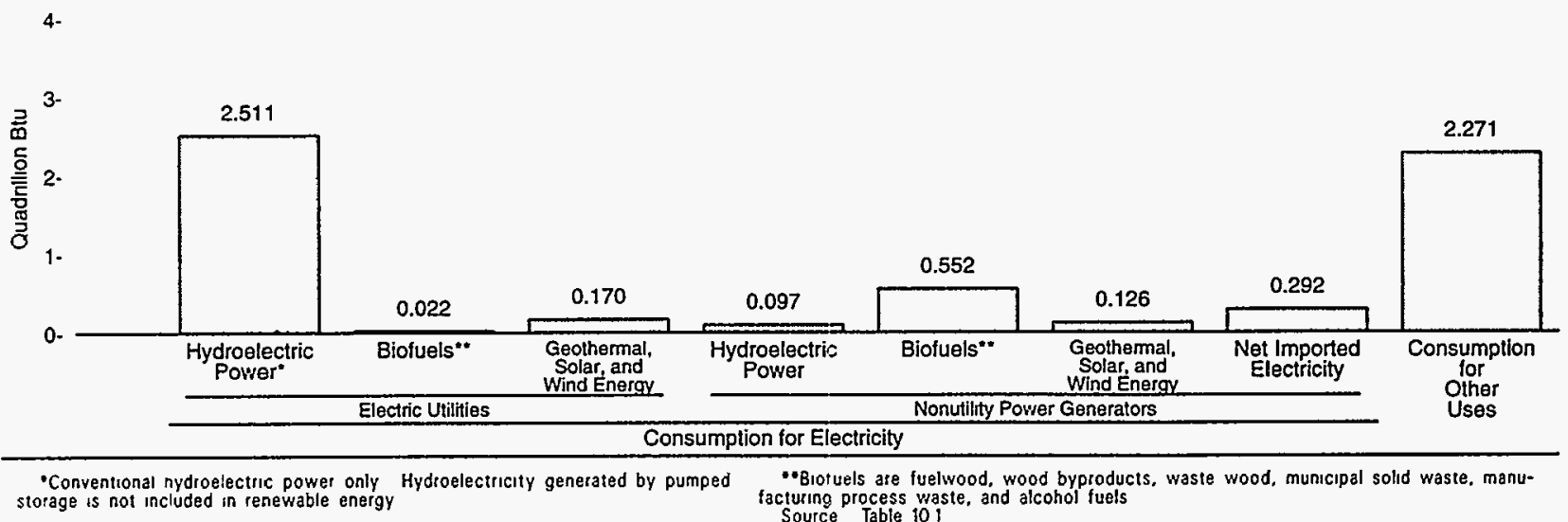

Source: Energy Information Administration, Annual Energy Review 1993, DOE/EIA-0384(93)(Washington, DC July 1994$).$

More information on this subject can be found in the following EIA publications: Annual Energy Review, Monthly Energy Review, and Electric Power Monthly. 


\section{Degree-Days}

Freezing winter weather or a long, sweltering summer--either one can increase your utility bills. But how much of the rise in the cost is a result of the weather? You can find out by using a unit of measure called the "degree-day."

A degree-day compares the outdoor temperature to a standard of 65 degrees Fahrenheit $(F)$ : the more extreme the temperature, the higher the number of degree-days. Thus, degree-day measurements can be used to describe the effect of outdoor temperature on the amount of energy needed for space heating or cooling.

Technically, a degree-day is a 1-degree $F$ difference between 65 degrees $F$ and the mean outdoor air temperature on a given day. Hot days, which may require the use of energy for cooling, are measured in cooling degree-days. On a day with a mean temperature of 80 degrees $F$, for example, 15 cooling degree-days would be recorded. Cold days are measured in heating degree-days. For a day with a mean temperature of 40 degrees F, 25 heating degree days would be recorded. Two such cold days would result in a total of 50 heating degree-days for the 2-day period.

By studying degree-day patterns in your area, you can evaluate the increases or decreases in your heating or air-conditioning bills from year to year. In some areas, degree-day information is published in the local newspapers, usually in the weather section. Information may also be available from your local utility. Its public relations department may be able to tell you the number of degree-days in the last billing period and how it compares to the number of degree-days in previous billing periods. You may also be able to obtain degree-day totals for longer periods.

By studying degree-day patterns for the United States, you can better understand changes in the U.S. energy consumption. Degree-day data for U.S. regions or the country as a whole usually are population-weighted, since hot or cold weather in a densely populated area affects energy use more than the same weather in a sparsely populated area.

EIA provides information about degree-days in its publication Monthly Energy Review. A degree-day table lists the population-weighted degree-days that occur in each region of the United States. It compares monthly and year-to-date totals to similar totals for previous periods.

The degree-day table on the next page shows that, in the Middle Atlantic States, January 1994 was colder than January 1993. In January 1994, 1,345 heating degree-days were recorded, up from 981 degree-days (colder than normal) in January 1993. On the other hand, the Pacific States were warmer in January 1994 (489 heating degree-days) than in January 1993 (599 heating degree-days), but cooler than normal.

The data show that, on average, the United States was colder in January 1994 than in January 1993, and colder than normal for both years. The National Oceanic and Atmospheric Administration (NOAA) is a second source of information about degree-days for the country as a whole. 


\section{Population-Weighted Heating Degree-Days}

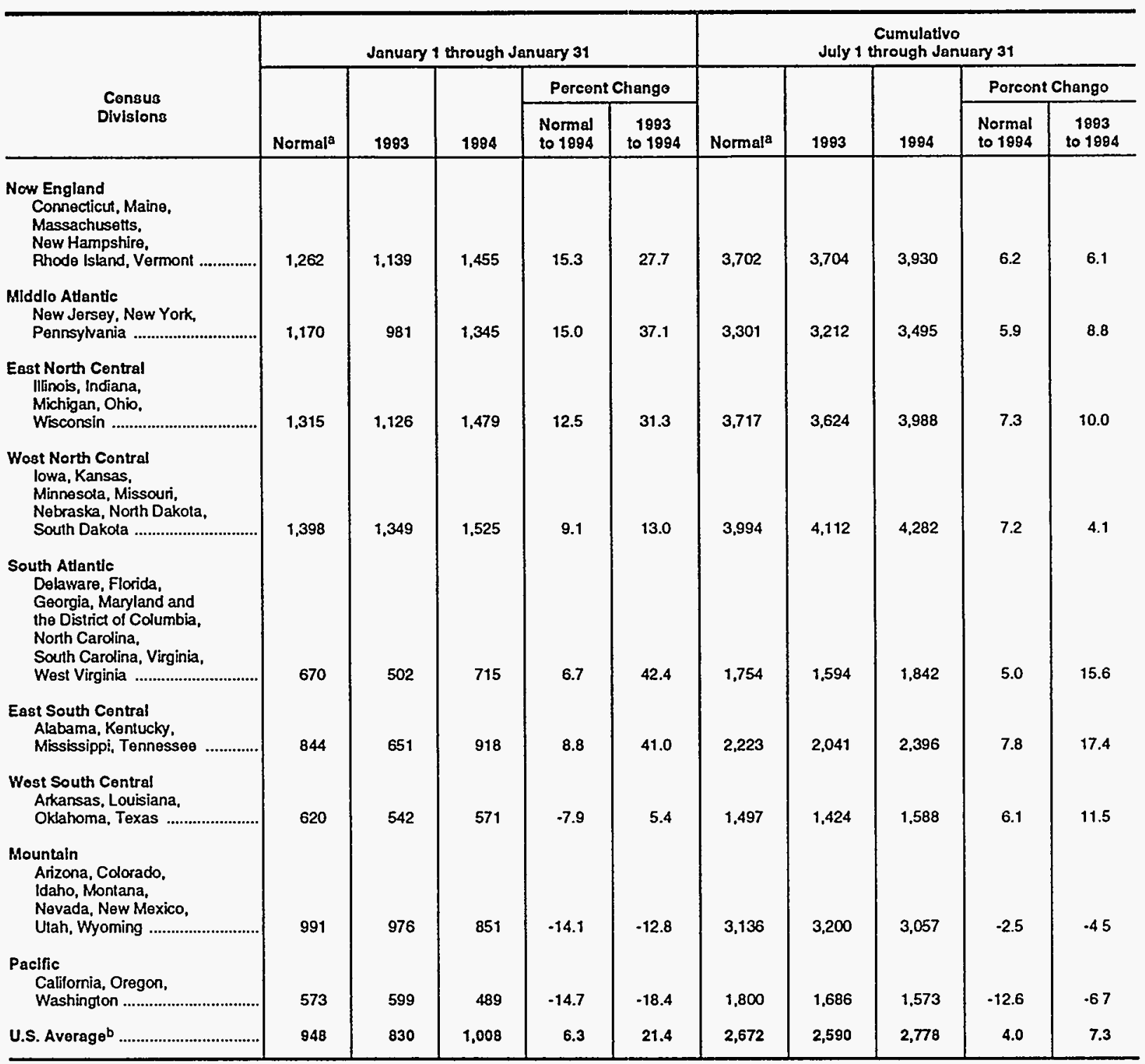

a "Normal" is based on calculations of data from 1961 through 1990.

Excludes Alaska and Hawaïi.

Source: Energy Information Administration, Monthly Energy Review, DOE/EIA-0035(94/02)(Washington, DC, February 1994).

More information on this subject can be found in the EIA publication Monthly Energy Review or from the National Climatic Data Center, Federal Building, Asheville, North Carolina 28801. 
Apples, Oranges, and Btu

Assume that you have been assigned the responsibility of purchasing fuel for a large electric utility company. The 1993 average prices of fuel delivered to electric utilities were $\$ 28.58$ per short ton of coal, $\$ 15.42$ per 42 -gallon barrel of oil, and $\$ 2.62$ per thousand cubic feet of natural gas. Tons, barrels, cubic feet--how do you compare apples and oranges?

To make meaningful comparisons of energy commodities, you must convert physical units of measure (such as weight or volume) and the energy content of each fuel to comparable units. One practical way to compare different fuels is to convert them into British thermal units (Btu). The Btu is a precise measure of energy--the amount of energy required to raise the temperature of 1 pound of water 1 degree Fahrenheit.

A single Btu is insignificant in terms of the Nation's energy consumption, or even in terms of energy use in a single household. One Btu is approximately equal to the energy released in the burning of a wood match. The average single-family household consumed 98 million Btu of energy in a recent year. So on the family level, 1 million Btu is a meaningful quantity.

Billions, trillions, and quadrillions of Btu are used to measure quantities of energy larger than those consumed by typical households. (Written out, 1 quadrillion is a 1 and 15 zeros.) To put those quantities in perspective, 1 million Btu equals about 8 gallons of motor gasoline. One billion Btu equals all the electricity that 30 average Americans use in 1 year. One trillion Btu is equal to 474 100-ton railroad cars of coal intended for electric utilities. And 1 quadrillion Btu is equal to 470 thousand barrels of oil every day for 1 year. In 1993, the Nation used 84 quadrillion Btu of energy: 34 quadrillion Btu of petroleum, 21 quadrillion Btu of natural gas, 19 quadrillion Btu of coal, and 10 quadrillion Btu of other energy sources.

British thermal units are useful for more than just calculating volumes of consumption. Price equivalents are usually expressed in cents per million Btu, and the homeowner often thinks of Btu in terms of dollars and cents. In 1993, a ton of coal used to generate electricity cost more than twice as much as a barrel of oil. The barrel of oil, however, contained about 6.2 million Btu, while the ton of coal contained 21 million Btu, over three times as much energy. On a Btu basis, coal was cheaper. (Of course, cost is not the only consideration in selecting a fuel. Environmental restrictions, equipment costs, and other factors must also be taken into account.)

By use of the Btu, it is possible to compare prices not only for different forms of fuel, but also for different products from the same fuel. For example, motor gasoline contains an average of 5.25 million Btu per barrel, while jet fuel (kerosene-type) contains 5.67 million Btu per barrel. At $\$ 31.88$ per barrel for motor gasoline and $\$ 24.32$ per barrel for jet fuel in 1993, motor gasoline costs $\$ 6.07$ per million Btu and jet fuel costs $\$ 4.29$ per million Btu.

By itself, a single Btu does not mean very much. For the average consumer who uses millions of Btu per year, however, it is a term well worth knowing. 
More information on this subject can be found in the following EIA publications: Monthly Energy Review, Annual Energy Review, State Energy Data Report, Household Energy Consumption and Expenditures, and Cost and Quality of Fuels for Electric Utility Plants. 


\section{Residential Uses of Energy}

Surprisingly, most U.S. households (55 percent) wash dishes by hand. Only 45 percent of U.S. households use automatic dishwashers, but almost all households have hot running water for washing and cleaning, use a range or oven for cooking, and use a refrigerator for storing food. Very few households (1 percent) do not heat their homes because they live in warm areas such as Hawaii. All but 1 percent of households use a TV, and for most, it is a color television. More than half of U.S. households use a clothes washer at home (76 percent) and a clothes dryer (69 percent), have air conditioning (68 percent), cook with a microwave oven ( 79 percent), and are cooled by a window or ceiling fan ( 51 percent). Less than half of U.S. households use a food freezer that is separate from their refrigerator ( 35 percent), use a portable space heater (19 percent), a personal computer (16 percent), a water pump for their own water (15 percent), a water-bed heater (15 percent), a second refrigerator (15 percent), or a swimming pool at home (5 percent).

\section{Types of Energy Uses by Households}

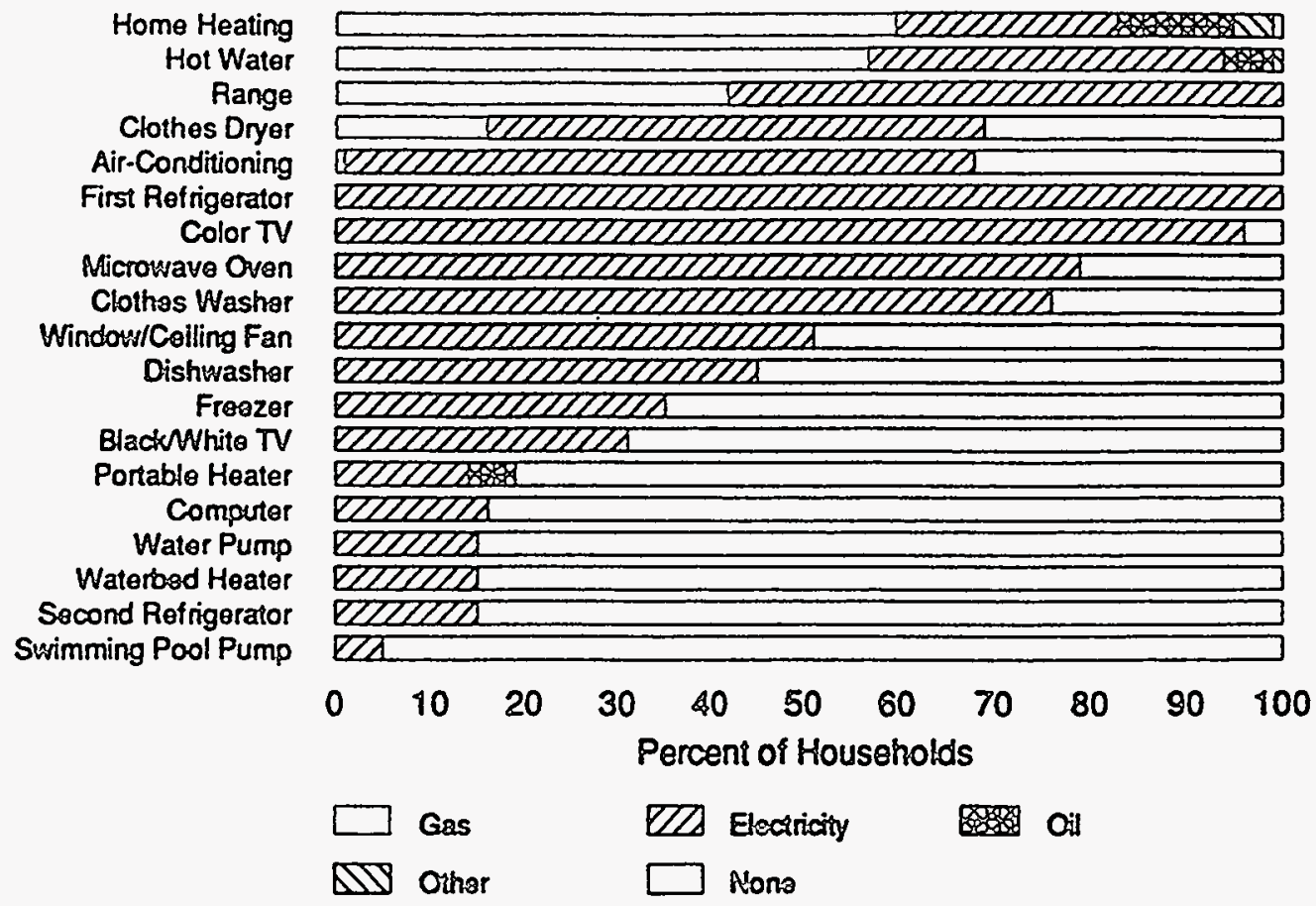

Source: Energy Information Administration, Housing Characteristics 1990, DOE/EIA-0314(90)(Washington, DC, May 1992).

Gas is the predominant energy source for home heating (60 percent) and for heating water (57 percent). Gas is also used for cooking and for drying clothes. Fewer than 1 percent cool their homes by burning gas. It may seem strange that one can cool anything by burning gas, but the process of cooking with gas 
is different from cooling with electricity. When cooling with gas, the gas is burned to boil off a cooling agent. With electricity cooling, a different cooling agent is used that works after it is compressed into a liquid form. Electricity is the most versatile energy source in a home. It is used for every purpose listed in the graph. Oil is now being used only for heating homes and for heating water.

More information on this subject can be found in the EIA publication Household Energy Consumption and Expenditures. 